SJ Quinney College of Law, University of Utah

Utah Law Digital Commons

$6-2020$

The Incomplete Rule of Completeness: Taking a Stand on Federal Rule of Evidence 106

Louisa Heiny

Emily Nuvan

Follow this and additional works at: https://dc.law.utah.edu/scholarship

Part of the Criminal Law Commons 


\title{
THE INCOMPLETE RULE OF COMPLETENESS: \\ TAKING A STAND ON FEDERAL RULE OF EVIDENCE 106
}

\section{LOUISA M. A. HEINY AND EMILY NUVAN ${ }^{1}$}

\begin{abstract}
The common law Rule of Completeness served an important role in Anglo-American jurisprudence for centuries. Historically, it was a rule guided by principles of fundamental fairness and was designed to prevent parties from introducing incomplete and misleading statements at trial.

What was once a simple rule has been muddled by Federal Rule of Evidence 106. The common law rule language was lost when Rule 106 was drafted, and there is no agreement as to what portion of the common law survived and what was left behind. Particularly problematic are the issues of whether Rule 106 applies to oral as well as written statements, and whether Rule 106 allows a court to admit otherwise inadmissible evidence. The federal and state courts are split on these issues, and the United States Supreme Court has failed to provide guidance.

This Article critically examines current Rule of Completeness jurisprudence. It compares and contrasts the common law with Rule 106, and then dives deeply into the disparate interpretations of the Rule. By using two recent Utah Supreme Court decisions as case studies, the Article highlights the confusion caused by the incomplete understanding of the Rule and demonstrates the unfairness that occurs when the Rule is read too narrowly. Finally, it recommends that the Federal Rules of Evidence Advisory Committee fill the leadership void in this area of Evidence law and draft an expanded Federal Rule of Evidence 106.
\end{abstract}

${ }^{1}$ Louisa M. A. Heiny is a Professor at the University of Utah S.J. Quinney College of Law. Emily Nuvan is a J.D. candidate at the University of Utah S.J. Quinney College of Law. 


\section{INTRODUCTION}

"[T]he greatest possibilities of error lie in trusting to a fragment of an utterance without knowing what the remainder was." ${ }^{2}$ - John Henry Wigmore, Wigmore on Evidence

In May of 2011, James Raphael Sanchez beat his girlfriend to death in an apartment in Salt Lake County, Utah. He admitted to "punching, slapping, kicking, stomping, grabbing" and repeatedly strangling the victim to unconsciousness before reviving her. ${ }^{3}$ Somewhere between

five and nine hours after the fight began, he strangled her for a final time by placing "his forearm across the front of her neck" and leaning into her. ${ }^{4}$ She blacked out. After attempts to revive her failed, Sanchez lay down next to her and fell asleep. When he awoke and found her dead, he called 911, left the door open for paramedics, and went to a friend's house. ${ }^{5}$ There "Sanchez took off his bloody pants and socks and took a nap."

Sanchez admitted to the crime but argued that he was entitled to the benefit of Utah's special mitigation statute. ${ }^{7}$ The jury was instructed that, were it to find that Sanchez had been under the influence of "extreme emotional distress" and that "a reasonable person facing the same situation would have reacted in a similar way," ${ }^{8}$ it should find Sanchez guilty of manslaughter rather than murder. ${ }^{9}$

27 WIGMORE ON EVIDENCE $§ 2094$, at 601 (Chadbourn rev. 1978).

${ }^{3}$ State v. Sanchez, 380 P.3d 375, 379, aff'd in part, vacated in part, 422 P.3d 866 (Utah 2018).

${ }^{4}$ Supra note 7 at 388 .

${ }^{5} \mathrm{Id}$.

${ }^{6}$ Supra note 7 at 379.

${ }^{7}$ See UtAH CODE ANN. § 76-5-205.5(1)(b) (stating that "special mitigation exists when the actor causes the death of another ... under the influence of extreme emotional distress for which there is a reasonable explanation or excuse".

${ }^{8}$ Supra note 7 at 387.

${ }^{9}$ UtAH CODE ANN. § 76-5-205.5(1)(b)(iii). 
At trial, the prosecution called the investigating detective to the stand. He testified on direct examination that he interviewed Sanchez after he was arrested, and that Sanchez admitted to the assault. ${ }^{10}$ On cross-examination the defense attempted to elicit additional evidence about the interview in order to prove special mitigation. Sanchez told police that during the attack he was " "under extreme emotional distress caused by [the victim] repeatedly telling him that she was cheating on him with his brother.' To establish the requisite extreme emotional distress, Sanchez sought to admit his statement to police that 'he started fighting with [Victim] because he thought she was cheating on him with ... his brother.' He said "this enraged him," that Victim "admitted it and she kept saying it," and "that hurt [his] feelings." 11 The prosecution, however, objected that the testimony was inadmissible hearsay, and the trial court agreed. Although Sanchez could have testified to this information himself, he chose not to testify. Sanchez was ultimately convicted of first-degree murder. ${ }^{12}$

The prosecution in Sanchez exploited a gap in the Rules of Evidence in order to tell a somewhat slanted story. Because Sanchez's out of court hearsay statement was admissible under Rule 801 (d) as the statement of an opposing party when offered by the prosecution, but inadmissible when offered by Sanchez himself, the prosecution was able to artfully cut portions of Sanchez's statements. As a result, Sanchez was forced to choose the lesser of two evils: either allow the prosecution to present a technically correct but incomplete version of his statement or, alternatively, surrender his Fifth Amendment rights and testify in order to clarify the record.

The common law recognized the damage caused by incomplete statements and addressed the problem through the Rule of Completeness. Under that Rule, "[i]n evidencing the tenor of an

\footnotetext{
${ }^{10}$ Supra note 1 at 379.

${ }^{11}$ Supra note 1 at 387-88.

12 Sanchez was also convicted of obstruction of justice.
} 
utterance material or relevant, made in words, whether written or oral, in original or in copy, the whole of the utterance on a single topic or transaction must be taken together." 13 The states adopted this broad common law principle into their own rules of evidence early in the nation's history, and the drafters of the Federal Rules of Evidence further built upon that effort when the principle was codified as Federal Rule of Evidence 106. ${ }^{14}$ Under Rule 106, "[i]f a party introduces all or part of a writing or recorded statement, an adverse party may require the introduction at that time, of any other part—or any other writing or recorded statement— that in fairness ought to be considered at the same time." 15

Although the common law Rule of Completeness and Rule 106 are similar, they vary in three significant ways. First, Rule 106 omits any reference to oral statements, making it unclear whether the Rule applies only to written and recorded statements or applies to oral statements as well. Second, Rule 106 adds a timing component that was not present in the common law rule, allowing the opposing party to stop the proceedings and demand the immediate introduction of the remainder of the statement. Finally, Rule 106 fails to address whether a statement must be independently admissible before a party may invoke Rule 106.

As a result of these gaps in the Rule, a significant split has developed among both state and federal courts. ${ }^{16}$ Some jurisdictions interpret Rule 106 narrowly. These jurisdictions refuse to apply Rule 106 to oral statements. Further, they only apply Rule 106 to written and recorded statements that are independently admissible. If the missing portion of the statement is

\footnotetext{
${ }^{13}$ Wright ET AL., supra note 2 (quoting WigMORE, CODE OF EvidENCE, 371-379 (3d ed. 1942)).

${ }^{14}$ Wright ET AL., supra note 2, at $§ 5001$; see also Harold F. Baker, Completing the Rule of Completeness: Amending Rule 106 of the Federal Rules of Evidence, 51 CREIGHTON L. REV. 281, 286 \& n. 23 (2018) ("Put simply, Rule 106 evolved from the common law, was adopted as a state rule, and was finally codified in the Federal Rules of Evidence.").

${ }^{15}$ Fed. R. Evid. 106.

${ }^{16}$ See infra Section III.
} 
inadmissible hearsay when offered by the party invoking Rule 106, it remains inadmissible. ${ }^{17}$ Other jurisdictions treat the Rule as an expansive expression of the common law rule. These courts apply Rule 106 to both oral and written statements. They also treat Rule 106 as a rule of admissibility. ${ }^{18}$ In the midst of this chaos, the United States Supreme Court has stood on the sidelines.

The purpose of this Article is to propose that the Federal Rules of Evidence Drafting Committee should redraft Rule 106 and follow those circuits and states that have adopted an expansive interpretation of the Rule. The Rule of Completeness was intended to apply to all statements, including those made orally, and to admit evidence that would otherwise be inadmissible for the purpose of correcting the manipulative use of incomplete statements at trial. As a result, it acted as a counterbalance to a method that trial lawyers have employed for centuries: "carefully trimming a quotation [so] they could tell the truth but use it like a lie."19

Section II reviews the history of the common law Rule of Completeness and compares it to the current embodiment in Rule 106. Section III addresses the current split among circuit and state courts and explains the reasons for the divergent approaches. Section III particularly explores how courts deal with two separate issues: (1) whether Rule 106 applies to oral statements; and (2) whether Rule 106 allows the admission of inadmissible evidence. Section IV examines two recent Utah Supreme Court decisions, State v. Sanchez and State v. Jones, that dealt with the interpretation of Rule 106. The two cases serve as case studies and highlight the need for advisory committee guidance in Rule 106 jurisprudence. Section V proposes amendments to Federal Rule of Evidence 106 that will reflect the purpose of the original

\footnotetext{
${ }^{17}$ See infra Section III.

18 See infra Section III.

19 21A Charles Alan Wright et Al., Fed. Prac. \& Proc. Evid. $§ 5072$ (2d ed.), Westlaw (database updated Sept. 2018).
} 
common law rule, while simultaneously ensuring that a broader interpretation will not allow parties to circumvent other important exclusionary rules of evidence. Section VI concludes with a discussion of how changes to the rule will ensure greater fairness and justice in the courtroom.

\section{History OF THE COMMON LAW Rule OF COMPLETENESS AND ITS EVOLUTION INTO RULE 106}

\section{A. THE COMMON LAW RULE OF COMPLETENESS}

The common law Rule of Completeness was "clearly conceded and consciously applied" in the law of evidence as early as the $1600 \mathrm{~s}^{20}$ The Rule was meant to prevent parties from introducing incomplete, and therefore misleading, statements. ${ }^{21}$ The principle behind the Rule was simple. According to Wigmore, statements, whether written or oral, are attempts to express ideas. ${ }^{22}$ To break these ideas into pieces and view each part in isolation "would be to obtain a false notion of the thought." ${ }^{23}$ Because "the presence or absence or change of a single word may substantially alter the true meaning of even the shortest sentence," 24 "the whole of a verbal utterance must be taken together" 25 in order to prevent injustice and misinterpretation. ${ }^{26}$

The common law Rule included three main features. First, the principle function of the doctrine was to allow otherwise inadmissible evidence to be used at trial for the purpose of completeness. ${ }^{27}$ This is known as the rule's "trumping function." 28 Thus, when incomplete and

${ }^{20} I d$. at 604 ("The recognition of the principle, and the reason for it are unquestionable ... [it] does no more than recognize the dictates of good sense and common experience.").

${ }^{21}$ See WRIGHT ET AL., supra note 2, at § 5072.1.

${ }^{22}$ WigMORE, supra note 1 , at 595.

${ }^{23} \mathrm{Id}$.

${ }^{24} I d$. at 597.

${ }^{25}$ WigMORE, supra note 1, at 604 (emphasis omitted).

${ }^{26} \mathrm{Id}$. at 595 ("One part cannot be separated and taken by itself without doing injustice, by producing misrepresentation.”).

${ }^{27}$ See WRIGHT ET AL., supra note 2, at $\S 5072.1$ (footnote omitted).

${ }^{28} \mathrm{Id}$. 
misleading evidence was offered, an opponent had the right to admit the remainder of the statement without regard to other applicable exclusionary rules. ${ }^{29}$

Second, the common law Rule applied to "every kind of utterance without distinction." 30 It applied to written and recorded statements, as well as acts, declarations, and conversations. ${ }^{31}$ The rule's broad scope reflected a recognition that "[a] misleading oral statement is no less unfair than a written one."32

Finally, the majority of courts applying the common law Rule did not permit or require acceleration under the Rule of Completeness. ${ }^{33}$ As a result, when one party offered incomplete and misleading evidence at trial, the adverse party was required to wait until cross-examination or the party's own case-in-chief before admitting the remainder of the statement.

While the common law Rule helped ensure a degree of fairness, it also posed a risk of abuse. Parties were consistently concerned that opponents would use the Rule to circumvent major exclusionary rules and admit copious amounts of irrelevant and inadmissible evidence in the name of completeness. ${ }^{34}$ As a result, the Rule was subject to important qualifications and exceptions designed to guard against potential abuses. ${ }^{35}$

First, under the common law, "[n]o utterance irrelevant to the issue is receivable." 36 This rather obvious limitation ensured that the Rule was used to clarify meaning and correct distortions, not admit irrelevant evidence — even when that evidence was a part of the same oral

\footnotetext{
${ }^{29}$ See WRIGHT ET AL., supra note 2 , at $\S 5072$.

307 WigMORE ON EVIDENCE $§ 2113$, at 654 (Chadbourn rev. 1978).

${ }^{31}$ See WRIGHT ET AL., supra note 2, at $\S 5072$.

${ }^{32}$ United States v. Bailey, 322 F. Supp. 3d 661, 674 (D. Md. 2017) (memorandum opinion).

33 See WRIGHT ET AL., supra note 2, at $\S 5072.1$.

34 See WigmORE, supra note 27, at 656.

${ }^{35}$ See WigmORE, supra note 1, at 604.

${ }^{36} I d$. (emphasis omitted).
} 
statement or writing. ${ }^{37}$

Second, "[n]o more of the remainder of the utterance than concerns the same subject, and is explanatory of the first part, is receivable." 38 As Wigmore explained, "The whole that is to be considered is obviously not the whole of a phrase or a paragraph," but "the whole of the thought." 39 Judges had significant flexibility and discretion ${ }^{40}$ to determine what material made up "the whole of the thought," particularly when the statement was part of a long or complex conversation. $^{41}$

Finally, "[t]he remainder thus received" was permitted only to "aid[] in the construction of the utterance as a whole[.] It was "not in itself testimony." ${ }^{42}$ This principle directly addressed the fear that a party would use the Rule of Completeness to furtively circumvent other exclusionary rules, particularly those against hearsay. This was especially a concern in criminal trials, where a defendant might use the Rule of Completeness to admit his own self-serving hearsay statements and, thus, avoid taking the stand on his own behalf. ${ }^{43}$

According to Wigmore, admitting the remainder of the statement for context but not for substance helped stem these abuses:

\footnotetext{
${ }^{37}$ See e.g., People v. Kent, 287 P.2d 402, 405 (Cal. App. 2d 1955) (“The rule that where part of a
} conversation has been shown in testimony the remainder of that conversation may be brought out by the opposing party, is necessarily subject to the qualification that the court may exclude those portions of the conversation not relevant to the items thereof which have been introduced."); Texas Cas. Ins. Co. v. Crawford, 340 S.W.2d 110, 112 (Tex. Civ. App. 1960) ("The rule authorizing the admission of the whole of a conversation where part of it has been introduced contemplates that the balance of the conversation will be relevant to and explanatory of the portion already introduced."); CAL. EVID. CODE $§ 356$ (2018) (California has used a codified version of the common law Rule of Completeness since 1872, and the committee notes to the current version of the Rule clarify that it "only makes admissible such parts of an act, declaration, conversation, or writing as are relevant to the part thereof previously given in evidence.").

38 WIGMORE, supra note 27, at 656 (emphasis omitted).

${ }^{39}$ See Wigmore, supra note 1 , at 604.

${ }^{40}$ See WigMORE, supra note 27 , at 659 \& n. 6 .

${ }^{41}$ See Wigmore, supra note 1, at 604.

${ }^{42}$ WigMORE, supra note 27, at 656 (emphasis omitted).

${ }^{43}$ See Baker, supra note 10, at 297-98. 
The remainder of the utterance, regarded as an assertion of the facts contained in

it, is merely a hearsay statement, and as such has no standing. It is considered by

the tribunal merely in order to piece out and interpret the first fragment and

ascertain whether as a whole the sense of the first becomes modified. ${ }^{44}$

For example, under the common law rule, when the prosecution offered the part of a defendant's confession to police officers stating, "I shot the man," the jury is led to believe the defendant is a confessed murderer. However, if the defendant was allowed to add the rest of the phrase, "but I did it out of self-defense," the effect was to eliminate the distortion created by the first fragment and provide a complete understanding of the entire phrase. In this situation, the whole expression showed a confession was made, but it was coupled with an explanation for the event. However, even if the reference to self-defense was material to the case, the completion evidence could be used to prove it. It could only be used to give meaning to the shortened statement. Once the misleading impression was removed, the completing evidence had no further legal effect. ${ }^{45}$

These three corollaries function as limits on the broad sweep of the common law Rule of Completeness but still preserve its purpose: the protection of parties from carefully trimmed statements that may unfairly mislead the jury and distort the truth.

The common law doctrine, including the Rule of Completeness, was first codified in its entirety by the influential Field Code in $1850 .{ }^{46}$ That Code, which was the first unified and

${ }^{44}$ WigmORE, supra note 27, at 659.

${ }^{45} I d$. at 660.

${ }^{46}$ The Field Code, named for its most enthusiastic drafter, David Dudley Field, was a code of civil procedure that "systematized New York's procedural law and combined the previously separate systems of common law and equity." Following New York's lead, thirty other American states and territories enacted their own versions of the code. See Kellen Funk, Equity Without Chancery: The Fusion of Law and Equity in the Field Code of Civil Procedure, New York 1846-76, 36 J. OF LegAL Hist. 152, 152-53 (2015). 
codified rules of civil procedure, stated:

Where part of an act, declaration, conversation, or writing is given in evidence by one party, the whole on the same subject may be inquired into by an adverse party; when a letter is read, the answer may be given; and when a detached act, declaration, conversation, or writing is given in evidence, any other act, declaration, conversation, or writing which is necessary to make it understood may also be given in evidence. ${ }^{47}$

This version of the Rule of Completeness served as a model for the Advisory Committee during the drafting process of Rule 106 for the Federal Rules of Evidence. ${ }^{48}$

\section{B. An EXAmination of Federal Rule of EVIDENCE 106}

The Federal Rules of Evidence, enacted in 1975, codified the Rule of Completeness. ${ }^{49}$ In its current state, Federal Rule of Evidence 106 provides that "If a party introduces all or part of a writing or recorded statement, an adverse party may require the introduction, at that time, of any

${ }^{47}$ See Code of Civil Procedure, N.Y. Commiss'Rs on PraC. ANd Pleading $§ 1687$, at 704-05 (1850). Several states, beginning with California in 1872, adopted this Field Code provision of the Rule of Completeness into their own evidence codes and continue to use it today. See WRIGHT ET AL., supra note 2, at § $5071 \&$ n. 70; see also CAL. EvID. CODE $\S 356$ (2018). Besides California, the other states where the Field Code is still in effect are Oregon, Nebraska, Iowa, and Texas. See Wright ET AL., supra note 2, at $\S 5078.2$, n. 9. reference).

${ }^{48}$ See FED. R. Evid. 106, Advisory Committee's Notes (listing California Evidence Code $\S 356$ as a

${ }^{49}$ Rule 106 was proposed in 1972 and adopted under the Act to Establish Rules of Evidence for Certain Courts and Proceedings, Pub. L. No. 93-595, 88 Stat. 1926 (1975) (In its original form, Rule 106 stated: "When a writing or recorded statement or part thereof is introduced by a party, an adverse party may require him at that time to introduce any other part or any other writing or recorded statement which ought in fairness to be considered contemporaneously with it."). 
other part — or any other writing or recorded statement — that in fairness ought to be considered at the same time."50 The Advisory Committee based the text on two considerations:: (1) "the misleading impression created by taking matters out of context" 51 ; and (2) "the inadequacy of repair work when delayed to a point later in the trial." ${ }^{52}$ Since its adoption, Rule 106 has only been amended twice - in 1987 and 2011 — but neither of these changes substantively affected the rule. $^{53}$

There are several notable differences between Rule 106 and its common law predecessor. First, Rule 106 contains an "acceleration clause," which allows an opponent to require the immediate introduction of completion evidence when the proponent has offered a truncated version of a statement. ${ }^{54}$ The rationale behind this function of the Rule has roots in the common law Rule of Completeness, which was concerned with abuses of the adversary system. ${ }^{55}$ Both versions guard against the damage caused to a party when a misleading half-truth is pulled from its context. $^{56}$

Rule 106, however, goes further than the common law. It recognizes that, in some cases, a false first impression cannot be adequately remedied by a "later, separate reading of the omitted parts." ${ }^{57}$ Distorted impressions, once perceived, "can sometimes linger and work [their] influence at the subconscious level." 58 A delayed review was, in the view of the Advisory

${ }^{50}$ FED. R. EVID. 106.

${ }^{51}$ FeD. R. Evid. 106, Advisory Committee's Notes (1972).

${ }^{52} I d$.

${ }^{53}$ Id. (1987 Amendments: "The amendments are technical. No substantive change is intended."; 2011 Amendments: The language of the rule was amended as part of the restyling of the Evidence Rules to make them more understandable and consistent throughout. The changes were purely stylistic.).

${ }^{54}$ See WRIGHT ET AL., supra note 2, at $\S 5072.1$.

${ }^{55} I d$.

${ }^{56}$ See 1 Charles T. McCormick et Al., McCormick on Evidence $§ 56$, at 392 (Kenneth S. Broun ed., 7th ed. 2013).

${ }^{57} \mathrm{Id}$.

${ }^{58}$ Id. See also WRIGHT ET AL., supra note 2, at $\S 5072.1$ for further examples of the danger of delay when misleading half-statements have been introduced by a proponent: 
Committee, a defect in the common law rule. The Committee sought to overcome its ill effects through the acceleration clause. ${ }^{59}$ Rule 106 gives the opponent not only the right to complete the truncated statement, but also grants the "further right to demand that the proponent expand the scope of his questioning" at the moment the misleading evidence is introduced. ${ }^{60}$

Second, Rule 106 only applies to incomplete writings and recorded statements, but not to oral statements. ${ }^{61}$ This was a purposeful narrowing of the common law rule. The Advisory Committee provided little detail on its reason for the change, stating only that, "for practical reasons, the rule ... does not apply to conversations." ${ }^{.62}$

Some courts and legal academics theorized that the Advisory Committee was trying to limit the problems caused by extensive oral statements with no clearly delineated beginning or end. ${ }^{63}$ As Wigmore noted, "oral utterances are not marked off as distinct wholes in the way that written utterances are. It is simple enough to see that one letter or one deed ends at the signatures ... but oral utterances can usually not be given any such separate unity of character ...."64 Moreover, oral statements are often heard by multiple witnesses, each of whom hear or remember one piece of the whole and discard the rest. ${ }^{65}$ The Advisory Committee may have also worried that sorting through these complications under the time pressure exerted by the

The opponent may suffer prejudice from the delay because the jury's evolving view of the case may have already been tainted by the time they hear the completing material. The jury may, of course, find it difficult to erase from its collective mind the misleading impression conveyed by the truncated version. But an equally grave risk of delayed completeness is that the jurors may recognize that the corrected version of the evidence may require them to go back and undo all the thinking they have done using the truncated version and evade that onerous task by giving the completing evidence less than the weight it deserves.

${ }^{59}$ See WriGHT ET AL., supra note 2, at § 5072.1.

${ }^{60}$ See MCCORMICK ET AL., supra note 57, at 393.

${ }^{61} \mathrm{See}$ FED. R. EVID. 106.

${ }^{62}$ FED. R. Evid. 106 Advisory Committee's Notes (1972).

${ }^{63}$ See WRIGHT ET AL., supra note 2, at $\S 5072.1$.

${ }^{64} 7$ WigMORE ON EVIDENCE $§ 2099$, at 619 (Chadbourn rev. 1978).

${ }^{65} \mathrm{Id}$. 
acceleration clause would disrupt the proponent's case. ${ }^{66}$

Third, the newly-enacted Rule 106 only allows a party to introduce completeness evidence when that evidence ought "in fairness . . to be considered at the same time." ${ }^{67}$ The common law version, conversely, allowed the introduction of completeness evidence "necessary to make [the incomplete evidence] understood." 68 This change in language provided trial judges with flexibility that they, up to that point, had not enjoyed. The common law Rule had developed into a rigid rule in which trial judges had little discretion. ${ }^{69}$ For example, if a party introduced one of a series of letters, the opposing party could automatically introduce the entire series on the same topic. ${ }^{70}$ The Advisory Committee intended to give judges more latitude than the common law allowed and used the fairness standard to achieve that goal. ${ }^{71}$ Now, no evidence is automatically admissible under Rule $106 .{ }^{72}$ However, the change in phrasing also injected a “morally tinged and discretionary standard” into Rule 106 analysis, giving trial court judges significant leeway to determine what is required by "fairness." 73

Fourth, Rule 106 is not an exclusionary rule. ${ }^{74}$ It does not give a party the power to prevent an opponent "from introducing an incomplete statement; it only gives the power to require that the statement be completed or to complete it himself." ${ }^{\prime 75}$ Courts may not exclude information that may be material to a case, but also must provide a remedy when that evidence is

${ }^{66}$ See WRIGHT ET AL., supra note 2 , at $§ 5072.1$.

${ }^{67}$ See FED. R. EvID. 106.

${ }^{68}$ CAL. Evid. CODE $\S 356$ (2018); see also WRIGHT ET AL., supra note 2, at $\S 5072.1$.

${ }^{69}$ See WRIGHT ET AL., supra note 2, at $\$ 5077$.

${ }^{70} \mathrm{See} i d$. (footnote omitted) (This is but one example of many automatic admissibility rules under the common law Rule of Completeness.).

${ }^{71}$ See id.

72 See id.

73 See Wright ET AL., supra note 2, at $\S 5072.1$.

${ }^{74}$ See WrIGHT ET AL., supra note 2, at $\S 5078$.

${ }^{75} \mathrm{Id}$. 
manipulated to create a misleading impression. ${ }^{76}$

Finally, Rule 106, unlike the common law Rule, is silent on the issue of admissibility. The drafters did not address whether Rule 106 allows completion evidence only if it would otherwise be independently admissible; ${ }^{77}$ or if, conversely, it functions as a rule of admissibility, allowing competition evidence that would ordinarily be barred by another rule. This silence created both a state and federal court split on the issue.

\section{HAS Rule 106 RePEALED AND RePlaCed the COMMON LAW Rule of COMPLETENESS?}

Although the Advisory Committee notes say nothing about admissibility, many courts refuse to admit evidence under the Rule of Completeness when that evidence is prohibited by other exclusionary rules. ${ }^{78}$ These courts, along with many state drafters and evidence scholars, believe that the only intended function of Rule 106 was "altering the order of proof to accelerate completeness." 79 As such, they believe the drafters of the Rule "must have abandoned the principle function of the common law completeness doctrine-allowing inadmissible evidence to be used for completion." 80

However, other state drafters and courts believe this reading of the Rule makes it "largely ineffectual in exactly those kinds of egregious abuse that spawned the common law completeness doctrine." ${ }^{81}$ As a result, these courts continue to follow the spirit of the common law Rule, using Rule 106 as a rule of admissibility.

\footnotetext{
${ }^{76} I d$.

77 See WRIGHT ET AL., supra note 2, at $\$ 5072.1$.

78 See infra Section III.

${ }^{79}$ See WRIGHT ET AL., supra note 2, at $\S 5072.1$.

${ }^{80} \mathrm{Id}$.

${ }^{81} I d$.
} 
These dueling interpretations of Rule 106 lead to further and ongoing questions: (1) is Rule 106 solely a rule that controls the timing of completeness evidence; and (2) if Rule 106 dropped the principle "trumping function" of the common law Rule of Completeness, did it also repeal the common law doctrine altogether, thus banning the introduction of otherwise admissible evidence previously allowed under the common law rule? ${ }^{82}$ Many lower courts, state drafters, and evidence writers reached divergent positions regarding these questions. ${ }^{83}$

The Supreme Court briefly waded into the disagreement surrounding the application of Rule 106 in Beech Aircraft Corp. v. Rainey ${ }^{84}$ In Beech Aircraft, a Navy training aircraft crashed, claiming the lives of a Navy flight instructor and her student pilot. ${ }^{85}$ Following the crash, the two pilots' surviving spouses sued the plane's manufacturer, claiming the crash was caused by a defect in the aircraft's fuel control system ${ }^{86}$ The manufacturer denied responsibility and instead claimed the reason for the crash was pilot error. ${ }^{87}$

In the weeks following the accident, the Navy produced a JAG investigative report. The deceased flight instructor's spouse, who was himself also a Navy flight instructor, took issue with the report and ${ }^{88}$ wrote a letter to the investigator outlining his own theory of the accident. ${ }^{89}$ In that letter he both challenged the JAG report's conclusions and included a detailed explanation of how mechanical failure caused the crash. ${ }^{90}$

Although the letter was hearsay, it was admissible when introduced at trial by the manufacturer as a statement of an opposing party under Federal Rule of Evidence 801(d)(2). The

\footnotetext{
${ }^{82}$ See id.

${ }^{83} \mathrm{Id}$. at $\S 5072.1 \& \mathrm{nn} .68-73$.

${ }^{84} 488$ U.S. 153 (1988).

${ }^{85} \mathrm{Id}$.

${ }^{86} \mathrm{Id}$. at $156-157$.

${ }^{87} \mathrm{Id}$. at 157.

${ }^{88} \mathrm{Id}$. at 159.

${ }^{89} \mathrm{Id}$.

${ }^{90}$ Id. at $170-171$.
} 
manufacturer therefore called the spouse as an adverse witness and introduced two portions of the letter. The first was a statement that the deceased flight instructor had attempted to cancel the flight the morning of the crash because of her student's fatigue. ${ }^{91}$ The second was a statement that, due to their own error, the two pilots were forced to initiate an abrupt maneuver when another plane unexpectedly came into view..$^{92}$ The spouse, who believed that the two admitted statements were taken out of context, attempted to correct any misrepresentation during crossexamination. The manufacturer objected. Somewhat surprisingly, the objection was not based on Rule 106, but rather that the question improperly asked for an opinion. The trial court sustained the objection, and the rest of the letter was excluded. ${ }^{93}$

The Supreme Court granted certiorari to consider, inter alia, whether the trial court erred in refusing to permit Rainey to present a more complete picture of what he had written[.]"'94 Despite possible preservation issues, the Court addressed the applicability of Rule 106. It had "no doubt that the jury was given a distorted and prejudicial impression" of the letter, and had the letter been read in its entirety, the jury would have seen that its true purpose was to propose that the accident was the result of a power failure. ${ }^{95}$ The Court also explained,

The common-law "rule of completeness," which underlies Federal Rule of Evidence 106, was designed to prevent exactly this type of prejudice ... [i]n proposing Rule 106, the Advisory Committee stressed that it 'does not in any way circumscribe the right of the adversary to develop the matter on cross-

\footnotetext{
${ }^{91} I d$. at 171.

${ }^{92} I d$.

${ }^{93} \mathrm{Id}$. at 160.

${ }^{94} I d$. at 170 .

${ }^{95} \mathrm{Id}$.
} 
examination or as part of his own case.' We take this to be a reaffirmation of the obvious: that when one party has made use of a portion of a document, such that misunderstanding or distortion can be averted only through presentation of another portion, the material required for completeness is ipso facto relevant and therefore admissible under Rules 401 and $402 .{ }^{96}$

The Court further acknowledged that "the Federal Rules of Evidence have partially codified the doctrine of completeness in Rule 106."997 Even though the concerns underlying the rule were clearly relevant in this case, the rule itself was not applicable, so the matter was resolved under the general rules of relevancy. The Court then explained it "need go no further in exploring the scope and meaning of Rule $106 .{ }^{98}$ And thus ended the Supreme Court's one-and-only glance into the controversy swirling around Rule 106 and its common law predecessor.

The majority of courts believe the Beech decision resolved the question of whether the common law Rule of Completeness survived the adoption of Rule $106^{99}$, holding that Rule 106 is a "complement" to the common law completeness doctrine. ${ }^{100 ~ " T h e ~ r e a s o n ~ i s ~ t h a t, ~ a s ~ t h e ~}$ Supreme Court itself appears to have recognized, Rule 106 only partially codifies the common law doctrine of completeness, and for situations beyond the reach of Rule 106, the common law still applies."101 The Alabama Rules of Evidence go so far as to say that Rule 106 "constitutes a

${ }^{96} \mathrm{Id}$. at $171-72$ (citation omitted).

${ }^{97} \mathrm{Id}$. at 172 (emphasis added).

${ }^{98} \mathrm{Id}$.

${ }^{99}$ See Wright ET AL., supra note 2, at $\S 5072.1$.

${ }^{100} I d$. at $\S 5072.1 \&$ n. 19.

${ }^{101}$ United States v. Bailey, 322 F.Supp. 3d 661, 670 (D. Md. 2017) (memorandum opinion). See also U.S. v. Lopez-Medina, 596 F.3d 716, 734 (10th Cir. 2010) ("The rule of completeness is a common law doctrine partially codified in Rule 106 of the Federal Rules of Evidence."); U.S. v. Wilkerson, 84 F.3d 692, 696 (4th Cir. 1996) ("The common-law doctrine of completeness has been partially codified in Rule 106 of the Federal Rules of Evidence."); State v. Leleae, 993 P.2d 232, 242 (Utah App. 1999) ("The common law rule of completeness ... is now partially found in Utah Rule of Evidence 106.”). 
specialized application of the common law completeness doctrine."102

Many legal scholars also take the position that the common law Rule of Completeness is alive and well. ${ }^{103}$ The writers of the Federal Practice and Procedure Treatise on Evidence, Wright \& Graham, stated, "While the decision can be read more narrowly ... we think the Court impliedly held that Rule 106 does not repeal the common law completeness doctrine."104 McCormick on Evidence further explains that when the Court indicated Rule 106 only "partially codified" the completeness doctrine, the implication was "that the uncodified aspect of the doctrine is still in effect in federal court." $" 105$

McCormick's view is especially persuasive when considering the Advisory Committee's Notes to Rule 106. The notes list $§ 56$ of McCormick’s evidence treaty, which is the location of the previous quote, as a reference for the rule. ${ }^{106}$ Moreover, the notes describe Rule 106 as "an expression of the rule of completeness." 107 This is not the kind of clear language one would expect if Rule 106 were meant to displace the common law.

Although it seems the Supreme Court indicated in the Beech case that the common law Rule of Completeness is still applicable when evidence falls outside the scope of Rule 106, the Court did not follow its own suggestion. Rather than reach its decision through a completeness analysis, it arrived at its conclusion via relevance instead. ${ }^{108}$ The Court, therefore, gave no

${ }^{102}$ Ala. R. Evid. 106, Advisory Committee's Notes (The notes further explain that "[t]his rule is not intended to affect preexisting Alabama applications of the completeness doctrine that lie outside the confines of Rule 106," and then lists several examples of when the common law completeness doctrine should be applied rather than Rule 106.).

${ }^{103}$ See WRIGHT ET AL., supra note 2, at $\S 5072.1$.

${ }^{104}$ Id. See also Baker, supra note 10, at 288 ("[I]t should be noted that Beech Aircraft Corp. v. Rainey suggests that the common-law Rule of Completeness is not dead; rather, it remains as a counterpart to the codified rule.").

${ }^{105}$ MCCORMICK ET AL., supra note 57, at 392-93, n. 5.

${ }^{106}$ FED. R. EvID. 106, Advisory Committee's Notes (1972).

${ }^{107} \mathrm{Id}$. (emphasis added).

${ }^{108}$ See Baker, supra note 10, at 288, n. 37. 
indication of when the common law doctrine may be used in lieu of Rule 106 or to what extent the common law rule still exists. ${ }^{109}$ This ambiguity has led to a wide divergence of interpretation among the federal circuits and state courts.

\section{THE INTERPRETATION OF RULE 106 SPLits the FedERAL CirCUITS AND tHE StATES}

Not only has the United States Supreme Court failed to provide guidance on the meaning of Rule 106, but the Federal Rules of Evidence Advisory Committee has also declined to consider the problem. ${ }^{110}$ As early as 1997 , the Committee recognized the split of authority among the circuits, yet declined to address the issue. ${ }^{111}$ Since that time, the split has only grown and encompasses more questions. ${ }^{112}$ At a meeting on October 18, 2002, the Committee considered two issues related to Rule 106: (1) whether the scope of Rule 106 should be extended to cover oral statements and acts; and (2) whether the Rule should explicitly include a "trumping function," which would allow otherwise inadmissible evidence to be offered for the purpose of completion. ${ }^{113}$

Following further discussion, the Committee declined to amend the Rule on the grounds "that the costs of amending Rule $106 \ldots$ were far outweighed by the risks that a change in language would be misinterpreted, and concluded that any problems under the current rule were

${ }^{109} I d$.

110 See Wright ET AL., supra note 2, at § 5071, Proposals to Amend Rule 106.

${ }^{111}$ See Advisory Comm. on Evidence Rules, Minutes of Meeting of April 14-15, 1997, at 10 (The Committee discussed the split between the circuits on the issue of whether Rule 106 allows inadmissible evidence to be used for completion purposes.).

112 See WrIGHT ET AL., supra note 2, at $§$ 5071, Proposals to Amend Rule 106 (explaining the committee was made aware that "despite the limitation in Rule 106 to written statements, many courts had required completeness in oral statements ... [and] some courts had used Rule 106 as 'a de facto hearsay exception.') (footnotes omitted).

${ }^{113}$ See Advisory Comm. on Evidence Rules, Minutes of Meeting of October 18, 2002, at 3. 
being well-handled by the courts." 114 The result has been a jumble of conflicting interpretations and application. The federal circuit courts remain in conflict, and the state courts, which are not bound by the federal circuits on this issue ${ }^{115}$, often ignore the views of local federal courts and forge their own path. ${ }^{116}$ There are even examples of conflicts within individual circuits and states. $^{117}$

This section will address these conflicting opinions, beginning with the issue of whether Rule 106 applies to oral statements and how both the federal circuits and state courts view the matter. It will also discuss the reasoning behind various positions and explain how Rule 106 interacts with Rule 611(a). This section will then look at the difficult problem of whether otherwise inadmissible evidence should be allowed for the purpose of completion evidence and analyze the split of authority at both the federal and state levels.

\section{A. The Application of Rule 106 to Oral StATEMENTS}

Rule 106 is clear that it applies only to writings and recorded statements. ${ }^{118}$ The Advisory

${ }^{114}$ Advisory Comm. on Evidence Rules, Minutes of Meeting of April 25, 2003, at 9; see also Andrea N. Kochert, The Admission of Hearsay Through Rule 106: And Now You Know the Rest of the Story, 46 IND. L. REV. 499, Section III (2013) for a discussion of how a court's interpretation of Rule 106 has a real impact on cases. Kochert takes issue with the October 2002 memorandum prepared by the Reporter for the Advisory Committee on Evidence Rules, in which he "noted that while the courts appeared to be in a dispute over the existence of a trumping function, this dispute [did] not appear to make a real difference in the cases." Kochert offers the example of United States v. Holden, 557 F.3d 698 (6th Cir. 2009) to disprove this assumption. The rule is not just an academic problem but a practical one as well, and it needs to be addressed.

${ }^{115}$ See infra, Section III.A.2.

116 The classic example of this is California, which did not adopt a version of Rule 106 but instead retained its own version of the common law Rule of Completeness. See CAL. EVID. CODE $§ 356$ (2018). California's rule extends to oral conversations and allows otherwise inadmissible evidence to be considered. Meanwhile, the 9th Circuit strictly interprets Rule 106 and does not consider oral statements or inadmissible evidence under its doctrine of completeness. See, e.g., U.S. v. Ortega, 203 F.3d 675, 682 (9th Cir. 2000).

${ }^{117}$ See, e.g., a comparison of the 4th Cir. cases U.S. v. Wilkerson, 84 F.3d 692, 696 (4th Cir. 1996) and U.S. v. Gravely 840 F.2d 1156, 1163 (4th Cir. 1988). The two cases, discussed infra, Section III.B.3.a reach completely opposite conclusions on the applicability of otherwise inadmissible evidence used under Rule 106; see also infra, Section IV for a discussion of the inconsistent application of Rule 106 by Utah courts.

${ }^{118}$ See FED. R. EVID. 106. 
Committee explained that "[f]or practical reasons, the rule is limited ... and does not apply to conversations." 119 Although the Committee had legitimate concerns in mind, ${ }^{120}$ there are situations where the truncated use of an oral statement puts a party at a serious disadvantage, particularly in criminal trials. ${ }^{121}$ This section will look at where the federal circuit courts and state courts fall on the issue of the admissibility of oral statements under Rule 106 and examine the reasoning behind their positions.

(1) Federal Circuit Courts that Allow Oral Statements to be Used as Completion Evidence

Many federal circuit courts, recognizing that Rule 106 does not permit the admission of oral statements for completeness, approve the admission of oral completeness statements under Rule 611(a). ${ }^{122}$ That provision states, "[t]he court should exercise reasonable control over the mode and order of examining witnesses and presenting evidence ...."123 Like the discretion provided by the common law rule of completeness, Rule 611(a) is designed to "make [the presentation of evidence] effective for determining truth." 124

At least four circuit have chosen to extend the rule of completeness to oral statements via Rule 611(a). These include the First, Sixth, Seventh, and Tenth Circuits. ${ }^{125}$ For example, the

119 See FED. R. EvID. 106, Advisory Committee's Notes (1972) (emphasis added).

${ }^{120}$ See discussion of problems associated with admitting oral conversations, supra p. 7, at 2 \& nn.62-67.

${ }^{121}$ See U.S. v. Bailey, 322 F.Supp.3d 661, 674 (D. Md. 2017) (memorandum opinion).

122 See WRIGHT ET AL., supra note 2, at $\$ 5074.1$.

${ }^{123}$ FED. R. EvID. 611(a).

${ }^{124}$ FED. R. EVID. 611(a)(1).

125 See, e.g., United States v. Verdugo, 617 F.3d 565, 579 (1st Cir. 2010) (explaining that the "short answer to this claim is that Rule 106 does not apply to testimony about unrecorded oral statements" but also acknowledging that "the district court retained substantial discretion under Fed.R.Evid. 611(a) to apply the rule of completeness to oral statements"); United States v. Branch, 91 F.3d 699, 727-28 (5th Cir. 1996) (noting, without disagreement, that other circuits "have held that Rule 611(a) imposes an obligation for conversations similar to what Rule 106 does for 
Seventh Circuit held that "by its terms the rule refers to written or recorded statements. However Rule 611(a) gives the district courts the same authority with respect to oral statements and testimonial proof." 126 This position is also supported by many evidence commentators, including McCormick, who posited that "the trial judge appears to have the same power to require the introduction of remainder of oral conversations under Federal ... Rule of Evidence 611(a)."127

The Second Circuit has long held that Rule 611(a) can be used to admit oral completeness evidence, ${ }^{128}$ but in a recent decision, it went a step further and explicitly adopted Wright \& Graham's position ${ }^{129}$ that oral statements are admissible under the common law rule of completeness and that the issue should have been put to rest in light of the Supreme Court's decision in Beech Aircraft Corp. v. Rainey. ${ }^{130}$ That case, at least according to Wright \& Graham, held that the common law completeness doctrine - which is not limited to written or recorded

writings."); United States v. Ford, 761 F.3d 641, 652 (6th Cir. 2014) ("The 'rule of completeness' allows a party to correct a misleading impression created by the introduction of part of a writing or conversation by introducing additional parts of it necessary to put the admitted portions in proper context. This common-law principle was codified for written statements in Federal Rule of Evidence 106, and ... extended to oral statements through interpretation of Federal Rule of Evidence 611(a).") (internal quotations and citations omitted); United States v. Lopez-Medina, 596 F.3d 716, 734 (10th Cir. 2010) ("While Rule 106 applies only to writings and recorded statements, we have held the rule of completeness embodied in Rule 106 'is substantially applicable to oral testimony, as well by virtue of Fed.R.Evid. 611(a), which obligates the court to make the interrogation and presentation effective for the ascertainment of the truth."') (quoting United States v. Mussaleen, 35 F.3d 692, 696 (2d Cir. 1994)).).

${ }^{126}$ United States v. Haddad, 10 F.3d 1252, 1258 (7th Cir. 1993) (The Court then cites several other Seventh Circuit cases that agree with this position.); see also United States v. Lewis, 954 F.2d 1386, 1392 (7th Cir.1992); United States v. Velasco, 953 F.2d 1467, 1475 (7th Cir.1992).

${ }^{127}$ MCCORMick ET AL., supra note 57, at 394, n.7; see also StePHEN A. SAltZBURG ET AL., FEDERAL RULES OF EVIDENCE MANUAL § 106.02[3], at 672-73 (11th ed. 2015):

While Rule 106 by its terms applies only to writings and recordings, the principle of completeness embodied in the rule has been applied to testimony about oral statements as well (such as a police officer's selective rendition of a defendant's oral statement). Whether this is mandated by Rule 106 or by Rule 611 is unimportant. The important point is that where a party introduces a portion of an oral statement, the adversary is entitled to have omitted portions introduced at the same time, insofar as that is necessary to correct any misimpression that the initially preferred portion would create.

${ }^{128}$ United States v. Mussaleen, 35 F.3d 692, 696 (2d Cir. 1994) ("While Rule 106 applies only to writings, we have previously explained that the rule of completeness is substantially applicable to oral testimony, as well by virtue of Fed.R.Evid. 611(a), which obligates the court to make the interrogation and presentation effective for the ascertainment of the truth.") (internal quotations omitted).

${ }^{129}$ See United States v. Williams, 930 F.3d 44, 58-59 (2d Cir. 2019).

${ }^{130} 488$ U.S. 153, 171 (1988). 
statements - survived the enactment of the Federal Rules of Evidence, including Rules 106 and 611(a). ${ }^{131}$ In United States v. Williams, the Second Circuit concluded that, although Rule 106 does not cover oral statements, "the common law rule of completeness is substantially broader than Rule 106, covering . . . the truncated use of acts, declarations, and conversations ... [a]nd as the Supreme Court made clear in Beech Aircraft Corp. v. Rainey, the common law doctrine persists in the wake of Rule 106's adoption." 132 The Second Circuit is the only federal circuit court to use the common law Rule of Completeness to admit oral statements for completion purposes. $^{133}$

Although many federal circuits have adopted the process of using Rule 611(a) to admit oral testimony for completion purposes, the same principles of relevance and fairness that constrain the use of Rule 106 apply equally to Rule 611(a). Rule 611(a), like Rule 106, "permits introduction only of additional material that is relevant and is necessary to qualify, explain, or place into context the portion already introduced."134 Further, whether a court is operating under Rule 106 or 611(a), it must "remain guided by the overarching principle that it is the trial court's responsibility to exercise common sense and a sense of fairness to protect the rights of the parties while remaining ever mindful of the court's obligation to protect the interest of society in the ascertainment of the truth."135

\section{(2) State Courts that Allow Oral Statements to be Used as Completion Evidence}

${ }^{131}$ See WRIGHT ET AL., supra note 2, at $\S 5074.1$.

${ }^{132} I d$. at 59 (emphasis in original).

${ }^{133}$ Id. ("This Court has expressly recognized as to oral statements that Fed. R. Evid. 611(a) both 'empowers and obligates' district courts to require 'a party offering testimony as to an utterance to present fairly the "substance or effect" and context of that statement,' just as the common law doctrine requires." (quoting United States v. Castro, 813 F.2d 571, 576 (2d Cir. 1987)).

134845 F.2d 938, 944 (11th Cir. 1988).

${ }^{135}$ United States v. Castro, 813 F.2d 571, 576 (2d Cir. 1987). 
Because the completeness doctrine has no constitutional basis, neither Rule 106 nor the common law rule of completeness are binding on the states. ${ }^{136}$ Nevertheless, nearly all the states have some form of the rule, with many simply incorporating the language of Rule 106 into their own evidence codes. ${ }^{137}$ Several states, like the majority of federal circuits, allow oral completeness evidence under Rule 611(a). ${ }^{138}$

However, variation exists even within this approach. For example, one state court, although theoretically willing to apply Rule 611(a) to oral evidence, expressed concerns about the problems inherent in oral statements. ${ }^{139}$ As the Court correctly pointed out, "oral statements are not easy to parse[.]" ${ }^{140}$ It therefore declared that "treating oral statements identically to the written and recorded statements covered by rule 106 is inappropriate." ${ }^{141}$ While "the introduction of documents under the doctrine of oral completeness should be more narrowly confined than the introduction of statements under rule 106[,]"142 the appellate court concluded that trial courts retain discretion to admit these statements. At the same time, it declared that trial courts should consider a variety of factors, including trustworthiness and reliability, before performing a Rule 611 analysis. ${ }^{143}$

${ }^{136}$ See WrIGHT ET AL., supra note 2, at $\S 5072.2$.

${ }^{137}$ See WRIGHT ET AL., supra note 2, at $\S 5071$, State Adoptions.

${ }^{138}$ See, e.g., NO. DAK. R. EVID. 106 ("The rule is not a rule of admissibility, but rather one dealing with order of proof, and as such may be considered to be but a specific application of the general dictates of Rule 611."); Schreiber v. State, 973 So. 2d 1265, 1269 (Fla. Dist. Ct. App. 2008) (state courts have "interpreted" Rule 106 to apply to unrecorded oral statements).

${ }^{139}$ See State v. Cruz-Meza, 76 P.3d 1165, 1168 (Utah 2003).

${ }^{140} \mathrm{Id}$.

${ }^{141} \mathrm{Id}$.

${ }^{142} I d$.

${ }^{143}$ Id. at $1167-68$. The Court went on to explain its view by stating:

The Utah Rules of Evidence are not meant to codify the law of evidence, but to formulate guides from which the law of evidence can grow and develop. These rules therefore supply a fresh starting place for the law of evidence and do not present an ultimate end. Despite its exclusion from rule 106, the rule of oral completeness may assist courts in the growth and development of the law of evidence and has been invoked by the courts of other states 
Other states also march to the beat of their own drum, applying a wide variety of approaches to the admission of oral evidence. ${ }^{144}$ Some states rely on the precedent of the common law Rule of Completeness to allow oral statements. ${ }^{145}$ Others use a combined approach, allowing courts to admit oral completeness evidence under the common law and then use Rule 106 to accelerate that completeness. ${ }^{146}$ One state allows oral statements based on the application of their own state version of Rule $106,{ }^{147}$ while yet another combines Rule 106 with a Rule 403 analysis to determine whether to admit oral statements. ${ }^{148}$ And for states that adopted the Field Code version of the completeness doctrine, ${ }^{149}$ similar to California's rule, the problem of what to do about oral evidence never arises because that codification already "applies to oral statements and acts." 150

through rules similar to our rule 611 , which requires trial courts to make the interrogation and presentation [of evidence] effective for the ascertainment of the truth.

${ }^{144}$ For examples of the different approaches the states take in regard to oral evidence, see WRIGHT ET AL., supra note 2, at $\S 5074.1 \& \mathrm{nn} .8,10,19,21-24$ (citing that Nevada allows oral statements based on the application of their state version of Rule 106; Florida and Indiana rely on the precedent of the common law Rule of Completeness to allow oral statements; Maryland and West Virginia use a combined approach, admitting oral evidence under the common law Rule of Completeness and then using Rule 106 to accelerate that completeness; and Michigan combines Rule 106 with a Rule 403 analysis to determine whether to admit oral statements).

${ }^{145}$ Mississippi's Rule of Evidence 106 is an exact copy of the federal version, but in the Advisory Committee's notes it states, "This rule is a codification of the common law doctrine of completeness ... However, Rule 106 is somewhat narrower than Mississippi common law. The rule only applies ... to written or recorded statements ... Under Mississippi case law the rule of completeness is extended to other writings and even to oral statements." See Miss. R. EvID. 106, Advisory Committee Notes; see also Whitfield v. State, 933 So.2d 1245, 1248 (Fla. Dist. Ct. App. 2006) (while conceding that the language of Fla. Evid. Code $§ 90.108(1)$ suggests the statute only applies to writings or recorded statements, the court applied Florida precedent applying completeness doctrine to conversations); Barnett v. State, 916 N.E.2d 280, 286 (Ind. Ct. App. 2009) (explaining that the Court has always held that the common law doctrine of completeness applies to oral conversations as well as writings).

${ }^{146}$ Maryland and West Virginia use the combined approach. See WRIGHT ET AL., supra note 2, at $\S 5074.1$ $\&$ nn.21, 23.

${ }^{147}$ See Domingues v. State, 917 P.2d 1364, 1372 (Nev. 1996) (explaining that Nevada allows oral statements based on the application of their state version of Rule 106).

${ }^{148}$ Michigan's court rules suggest that this is the process Rule 106 analysis would take. See 1 RoBINSON, Longhofer \& AnKers, Michigan Court Rules Practice: Evidence 88 (2d ed. 2002).

${ }^{149}$ These states include California, Oregon, Nebraska, Iowa, Montana, and Texas. See WrIGHT ET AL., supra note 2, at § 5071, State Adoptions.

${ }^{150}$ See WRIGHT ET AL., supra note 2, at $\S 5074.1$. 


\section{(3) Federal Circuit Courts and State Courts that Reject the use of Oral}

\section{Statements Under Rule 106}

Some state and federal courts, including the Fourth, Fifth, and Ninth Circuits, strictly enforce the distinction made by Rule 106 between oral statements and their written or recorded counterparts. ${ }^{151}$ In some circumstances, this rule has had the unintended consequence of encouraging police officers to take oral, rather than recorded or written, confessions from suspects unless they are convinced that the statement will be completely inculpatory. ${ }^{152}$ Further, it may encourage prosecutors to rely only on oral testimony, even when written or recorded evidence is available and admissible. For example, in United States v. Garcia, the Court held that Rule 106 was not applicable to oral statements, even when an immigration officer testified from memory about an interrogation he conducted with the defendant. The interrogation was recorded, but the recording was never submitted as evidence at trial. ${ }^{153}$ The court denied the defendant's request to introduce the recording as completion evidence because the prosecution had not itself introduced the recorded statements. Rather, the court held that "Rule 106 does not apply to a witness's testimony at trial" nor is simply quoting from a transcript tantamount to admittance of the evidence. ${ }^{154}$

${ }^{151}$ See Wright ET AL., supra note 2, at $\S 5074.1 \& \mathrm{nn} .8,20,25$ (citing that Alabama rejects oral statements because its version of Rule 106 does not allow them; Colorado and New Hampshire reject oral statements because their courts have found that the common law Rule of Completeness did not survive the passage of Rule 106; and Kentucky prohibits defendants from using the completeness doctrine to require witnesses to include exculpatory portions of an oral confession).

${ }^{152}$ See, e.g., United States v. Ortega, 203 F.3d 675, 682 (9th Cir. 2000) (“'[T]he rule of completeness ... applies only to written and recorded statements. Because the officer's testimony concerned an unrecorded oral confession, the rule of completeness does not apply."); United States v. Wilkerson, 84 F.3d 692, 696 (4th Cir. 1996) (The defendant was not allowed to cross-examine an FBI agent about exculpatory statements he allegedly made because "[t]he rule only applies to writings or recorded statements, not to conversations."); State v. Thibeault, 621 A.2d 418, 422 (Me. 1993) (raising the concern that if defendants aren't allowed to complete their oral confessions, police officers would only record those statements that were completely inculpatory).

${ }^{153} 530$ F.3d 348 (5th Cir. 2008).

${ }^{154} I d$. at 353. 


\section{B. The Application of Rule 106 Apply to Evidence that Would Be OtheRWise}

\section{INADMISSIBLE}

The question of admissibility under Rule 106 is complex and disputed. ${ }^{155}$ Nothing in the rule's language, nor in the Advisory Committee's notes "limits the material used for completeness to evidence that satisfies the requirements of the other exclusionary rules. Unlike the Rules that were made subject to other exclusionary doctrines, it does not contain an 'except as otherwise provided' clause." 156 At the same time, nothing in the rule language or notes explicitly provides for the admission of evidence that would normally be prohibited by another exclusionary rule.

As a result, Rule 106 can be read in two ways. Either Rule 106 simply governs the timing of presenting evidence, or it may be treated as retaining the "trumping function" it had under the common law, which allowed evidence that would otherwise be inadmissible under other exclusionary rules. ${ }^{157}$ This section will look at where the federal circuit courts and state courts fall on the issue and examine the reasoning behind their positions.

(1) Federal Circuit Courts and State Courts which Hold that Rule 106 is About Timing and Nothing Else

${ }^{155}$ Unlike the question regarding Rule 106's applicability to oral statements, Rule 611(a) cannot be used in this situation. See WRIGHT ET AL., supra note 2, at $§ 5072.2$ ("Rule 611 does not purport to give the trial judge any power to admit inadmissible evidence.").

${ }^{156}$ WRIGHT ET AL., supra note 2, at $\S 5078.1$.

${ }^{157} I d$. 
Some courts conclude that Rule 106 "does not compel admission of otherwise inadmissible hearsay evidence." ${ }^{158}$ Courts that subscribe to this version of the doctrine interpret the rule as solely governing evidence that would otherwise be admissible under the rules and "simply allowing for its introduction at a more appropriate time." 159 These courts are primarily concerned about parties who use Rule 106 to introduce evidence that circumvents major exclusionary rules, ${ }^{160}$ particularly criminal defendants who use the rule to introduce inadmissible, self-serving exculpatory statements - without testifying themselves - under the cover of completeness. ${ }^{161}$

For example, a defendant might make oral or recorded statements to the police. Although hearsay, these statements are admissible under Rule $801(\mathrm{~d})(2)^{162}$ when offered by the prosecution at the defendant's trial. ${ }^{163}$ These "[a]dmissions by a party-opponent are excluded from the category of hearsay on the theory that their admissibility in evidence is the result of the adversary system rather than satisfaction of the conditions of the hearsay rule." ${ }^{164}$ In other words, an opposing party's statement is allowed admittance because "a party opponent is already present in a proceeding to explain, justify, or even deny an alleged omission." ${ }^{165}$ Therefore, if the prosecution only admits the inculpatory statements made by a defendant to the police, as is often the case, the defendant has the ability to take the stand and rebut those statements with the exculpatory statements that were also made. Because the defendant has the ability to counteract

${ }^{158}$ U.S. Football League v. National Football League, 842 F.2d 1335, 1375-76 (2d Cir. 1988).

${ }^{159}$ See Baker, supra note 10, at 297.

${ }^{160} \mathrm{Id}$.

${ }^{161} I d$. at 298.

${ }^{162}$ See FED. R. EvID. 801(d)(2) An opposing party's statement may be offered against the opposing party at trial because such statements are not considered hearsay.

${ }^{163}$ See FeD. R. EviD. 801 Advisory Committee Note to Subdivision (d), at (2)(A) (1972 Proposed Rules) (Stating that "[a] party's own statement is the classic example of an admission.").

${ }^{164} I d$. at $801(2)$.

1652 Charles T. MCCORMick et Al., MCCORMicK On Evidence $§ 259$, at 295-96 (Kenneth S. Broun ed., 7th ed. 2013). 
these attacks, the courts see no reason for allowing inadmissible evidence to be admitted under Rule $106 .{ }^{166}$

A few federal circuits, including the $\operatorname{Sixth}^{167}$ and Ninth ${ }^{168}$, firmly and consistently hold that inadmissible evidence is not allowed under Rule 106. In one memorable case from the Sixth Circuit, the Court acknowledged the unfairness of not allowing completion evidence when the government significantly and inaccurately cropped the transcribed statements of the defendants and presented them as evidence at trial. ${ }^{169}$ Although it agreed "that these examples highlight the government's unfair presentation of the evidence, this court's bar against admitting hearsay under Rule 106 leaves defendants without redress." ${ }^{170}$ These circuits see Rule 106 as inflexible in its application, no matter how egregious the conduct of the party admitting misleading evidence. At least a dozen states similarly bar the introduction of otherwise inadmissible evidence for completeness. $^{171}$

${ }^{166}$ United States v. Ford, 761 F.3d 641, 651-52 (6th Cir. 2014) (“Out-of-court statements made by a partyopponent are an exception to the general hearsay rule. This exception reflects that the adversarial process allows the party-declarant to rebut his or her own admissions by testifying at trial. This hearsay exception does not, however, extend to a party's attempt to introduce his or her own statements through the testimony of other witnesses.") (internal quotation marks and citations omitted).

${ }^{167}$ See United States v. Ford, 761 F.3d 641, 652 (6th Cir. 2014) ("[T] he rule of completeness 'is not designed to make something admissible that should be excluded.'”) (quoting United States v. Costner, 684 F.2d 370 , 373 (6th Cir. 1982); United States v. Adams, 722 F.3d 788, 826 (6th Cir. 2013) ("We have determined previously that Rule 106 covers an order of proof problem; it is not designed to make something admissible that should be excluded. Right or wrong, this court has acknowledged that ... exculpatory hearsay may not come in solely on the basis of completeness.") (internal quotation marks and citations omitted).

168 See United States v. Collicott, 92 F.3d 973, 983 (9th Cir. 1996) (adopting Second Circuit rule that "Rule 106 does not compel admission of otherwise inadmissible hearsay evidence.”) (citation omitted); United States v. Mitchell, 502 F.3d 931, 965 n. 9 (9th Cir. 2007) ("Rule 106 does not render admissible otherwise inadmissible hearsay."); United States v. Ortega, 203 F.3d 675, 682 (9th Cir. 2000) ("Because the officer's testimony concerned an unrecorded oral confession, the rule of completeness does not apply. Even if the rule of completeness did apply, exclusion of Ortega's exculpatory statements was proper because these statements would still have constituted inadmissible hearsay.").

169 See United States v. Adams, 722 F.3d 788, 826-27 (6th Cir. 2013).

${ }^{170} \mathrm{Id}$. at 827 .

${ }^{171}$ These states include Alaska, Arizona, Delaware, Indiana, Kentucky, Maryland, Minnesota, Montana, North Dakota, Ohio, Oregon, and Tennessee. See WrIGHT ET AL., supra note 2, at $\$ 5078.1$ (footnotes omitted). Oregon is an interesting case because it did not adopt a version of Federal Rule 106 into its evidence code. Instead, it adopted the Field Code version, which is a complete codification of the common law doctrine adopted in 1850. However, out of all the states that adopted the Field Code, only Oregon "wrote an explicit prohibition on the use of inadmissible evidence for completeness into its version of the Field Code." See WRIGHT ET AL., supra note 2, at $\S$ 
(2) Federal Circuit Courts and State Courts which Hold that Rule 106 Admits the

\section{Inadmissible}

Many courts have rejected the notion that only admissible evidence can be used to provide completion evidence under Rule 106. The D.C. Circuit issued one of the most influential opinions on the subject in United States v. Sutton. ${ }^{172}$ There, the Court recognized the primary purpose of the rule:

Rule 106 can adequately fulfill its function only by permitting the admission of some otherwise inadmissible evidence when the court finds in fairness that the proffered evidence should be considered contemporaneously. A contrary construction raises the specter of distorted and misleading trials, and creates difficulties for both litigants and the trial court. ${ }^{173}$

Sutton considered the structure of Rule 106 and determined that "it is concerned with more than merely the order of proof." ${ }^{174}$ First, Rule 106 is not embedded in Rule 611, which governs the "Mode and Order of Examining Witnesses and Presenting Evidence." 175 Rather, it is located in Article I, "which contains rules that generally restrict the manner of applying the exclusionary

5078.2 \& n.8; see also note 45, supra. Although Maryland is included in this list, it is important to note that the Maryland judiciary holds that only its version of Rule 106 does not allow evidence that is otherwise inadmissible to be admitted. "However, where the evidence sought to be admitted is not otherwise admissible, the evidence may be admitted in fairness" under the common law doctrine of verbal completeness. See Otto v. State, 187 A.3d 47, 61 (Md. App. 2018).

172801 F.2d 1346 (D.C. Cir. 1986).

${ }^{173}$ Id. at 1368.

${ }^{174} \mathrm{Id}$.

${ }^{175}$ See FED. R. Evid. 611. 
rules." ${ }^{176}$ Further, Rule 106, unlike every other major rule of evidence, ${ }^{177}$ does not contain a proviso referring back to, or deferring to, other rules of evidence. Thus, it does not include the phrase "except as otherwise provided by these rules." 178 This absence indicates "that the draftsmen knew of the need to provide for relationships between rules and were familiar with a technique for doing this." ${ }^{179}$ The lack of such a proviso suggests "that Rule 106 should not be so restrictively construed." 180 Thus, when misleading evidence has been introduced, a trial court can use its discretion to "permit such limited portions [even if they are otherwise inadmissible] to be contemporaneously introduced as will remove the distortion that otherwise would accompany the evidence." 181 This approach, the court recognized, is the most likely to comport with Rule 102, which requires that the "rules of evidence be construed to secure fairness in administration ... [so] the truth may be ascertained and proceedings justly determined." 182 Finally, Sutton concluded that Rule 106's grounding in "fairness" should also be interpreted to include "the common-law requirements that the evidence be relevant, and be necessary to qualify or explain the already introduced evidence allegedly taken out of context."183

${ }^{176}$ Sutton, 801 F.2d at 1368 (citation omitted).

${ }_{177}$ See, e.g., FED. R. EvID. 402 (irrelevant evidence), 501 (privileges), 602 (lack of personal knowledge), 613(b) (examining witness concerning prior statement), 704 (opinion on ultimate issue), 802 (hearsay), 806 (credibility of declarant), 901(b)(10) (methods of authentication), 1002 (original writing).

${ }^{178}$ Sutton, 801 F.2d at 1368 (footnotes omitted).

${ }^{179} I d$. (footnote omitted).

${ }^{180} \mathrm{Id}$. (footnote omitted).

${ }^{181} I d$. at 1369.

${ }^{182}$ Id.; see also FED. R. EvID. 102.

${ }^{183}$ Sutton, 801 F.2d at 1369. 
Along with the D.C. Circuit, the First, ${ }^{184}$ Second,,${ }^{185}$ Third, ${ }^{186}$ and Tenth Circuits ${ }^{187}$

support a broad reading of Rule 106 designed to conform with Rule $102,{ }^{188}$ with fairness as the lodestar. A recent Second Circuit opinion held that "when the omitted portion of a statement [which is otherwise inadmissible] is properly introduced to correct a misleading impression or place in context that portion already admitted, it is for this very reason admissible for a valid, nonhearsay purpose: to explain and ensure the fair understanding of the evidence that has already been introduced. ${ }^{189}$ Seven states agree, ${ }^{190}$ while two others occasionally and

${ }^{184}$ See United States v. Bucci, 525 F.3d 116, 133 (1st Cir. 2008) (First Circuit case law "unambiguously establishes that the rule of completeness may be invoked to facilitate the introduction of otherwise inadmissible evidence. Other circuits have held differently, but we adhere to our own precedent.") (internal citations omitted).

${ }^{185}$ Early decisions of the Second Circuit rejected a broad interpretation of Rule 106 and refused to admit completion evidence that was otherwise inadmissible. See, e.g., United States v. Guevara, 277 F.3d 111, 127 (2d Cir. 2001) ("Rule 106 does not 'render admissible evidence that is otherwise inadmissible.") (quoting United States v. Terry, 702 F.2d 299, 314 (2d Cir. 1983). However, beginning in 2007, the Second Circuit abruptly changed its position to the opposite viewpoint. See United States v. Johnson, 507 F.3d 793, 796 (2d Cir. 2007) ("[E]ven though a statement may be hearsay, an omitted portion of [the] statement must be placed in evidence if necessary to explain the omitted portion, to place the admitted portion in context, to avoid misleading the jury, or to ensure fair and impartial understanding of the admitted portion.") (internal quotations and citations omitted). Subsequent Second Circuit opinions have all relied on this holding to support a broad interpretation of Rule 106. See United States v. Kopp, 562 F.3d 141, 144 (2d Cir. 2009); United States v. Coplan, 703 F.3d 46, 85 (2d Cir. 2012); and United States v. Williams, 930 F.3d 44, 60 (2d Cir. 2019).

${ }^{186}$ See United States v. Green, 694 F. Supp. 107, 110 (E.D. Pa. 1988) (noting with approval the opinion of the D.C. Circuit that Rule 106 "permits the introduction of evidence that is otherwise inadmissible under other Federal Rules."), aff”d 875 F.2d 312 (3d Cir. 1989).

${ }^{187}$ The Tenth Circuit only recently adopted the position that Rule 106 allows the use of inadmissible evidence for completeness purposes. As late as 2001 in the case of Echo Acceptance Corp. v. Household Retail Servs., 267 F.3d 1068, 1089-90 (10th Cir. 2001), the Court noted that it was unclear whether Rule 106 could be read to permit inadmissible hearsay evidence and declined to resolve the issue. However, the court has since adopted a stronger opinion in favor of a broad application of Rule 106. See United States v. Lopez-Medina, 596 F.3d 716, 735-36 (10th Cir. 2010) ("Even if the fact allocution would be subject to a hearsay objection, that does not block its use when it is needed to provide context for a statement already admitted." The Court then cited to the cases of United States v. Bucci and United States v. Sutton for support of this position.); United States v. Harry, 816 F.3d 1268, 1279-80 (10th Cir. 2016) (discussing the inclusion of fairness in the text of Rule 106 and citing to United States v. Lopez-Medina as precedent. "This fairness principle can override the rule excluding hearsay.").

${ }^{188}$ See FED. R. EVID. 102 ("These rules should be construed so as to administer every proceeding fairly, eliminate unjustifiable expense and delay, and promote the development of evidence law, to the end of ascertaining the truth and securing a just determination."); For a discussion of how the Rule of Completeness and Rule 106 interact with the interest of finding truth, see generally Collin D. Hatcher, The Whole Truth or Anything But ...: How Fairness, Reliability, and the Rule of Completeness Affect the Jury's Truth-Seeking Function, 39 Am. J. Trial Advoc. 683 (Spring 2016).

${ }^{189}$ United States v. Williams, 930 F.3d 44, 60 (2d Cir. 2019) (emphasis in original).

${ }^{190}$ These states are Connecticut, Colorado, New Hampshire, Texas, West Virginia, and Wisconsin. See WRIGHT ET AL., supra note 2, at $\S 5078.1$. Delaware also recently joined this group of states. See Thompson v. State, 205 A.3d 827, 834 (Del. 2019) ("Rule 106 codifies the common law rule of completeness, and its purpose is to prevent misleading impressions which often result from taking matters out of context. In certain circumstances, Rule 
inconsistently adopt this analysis. ${ }^{191}$

\section{(3) Federal Circuits with Conflicting Opinions and New Approaches}

Contrary to most federal circuit courts, the Fourth Circuit has been unable to maintain a consistent stance on the admission of otherwise inadmissible evidence for the purposes of completion. Its caselaw reflects significant contradictions. Meanwhile, the Seventh Circuit has advocated for a different method of dealing with the question of inadmissible evidence altogether.

\section{(a) The Oscillating Position of the Fourth Circuit}

The Fourth Circuit is a Circuit in flux. In United States v. Gravely, the Court held that, after the defendant introduced prior grand jury testimony under Rule 804(b)(1)(B) of witnesses who claimed the fifth amendment right not to testify at trial, the government was also entitled to introduce the omitted portions of their testimony even though the statements admitted under Rule 801(b)(1)(B) were only admissible when offered against the government - the party who had a prior opportunity and similar motive to develop the former testimony. ${ }^{192}$ The omitted portions, while perhaps not admissible standing alone, are admissible as a remainder of a recorded statement. [Rule] 106 allows an adverse party to introduce any other part of a writing or recorded

106 can render otherwise inadmissible evidence, such as hearsay, admissible.") (internal quotation marks and footnotes omitted).

${ }^{191}$ Florida and Mississippi courts have occasionally allowed the use of otherwise inadmissible evidence for completion, but there are examples of the opposite position as well, so the ultimate outcome is uncertain. See WRIGHT ET AL., supra note 2, at $§ 5078.1 \&$ nn.80-81.

192840 F.2d 1156, 1163-64 (4th Cir. 1988); see also FED. R. EVID. 804(b)(1), which creates a hearsay exception for the former testimony of an unavailable declarant. 
statement which ought in fairness to be considered contemporaneously. The rule simply speaks the obvious notion that parties should not be able to lift selected portions out of context. ${ }^{193}$

Following Gravely, it seemed that the Fourth Circuit had adopted a broad reading of Rule 106. However, a few years later, in United States $v$. Wilkerson, the Court made an about-face and abruptly held that Rule 106 does not "render admissible the evidence which is otherwise inadmissible under the hearsay rules." ${ }^{194}$ In yet another case, United States v. Bollin, the Court hinted that the Gravely view was not completely abandoned. ${ }^{195}$ Instead, "[t]he fact that some of the omitted testimony arguably was exculpatory does not, without more, make it admissible under the rule of completeness."196 The Court suggested that if excluded testimony is relevant and necessary to avoid misleading the jury or place the admitted testimony in context, it may provide the "something more," regardless of whether the evidence is independently admissible. ${ }^{197}$

In response to this uncertainty, a federal district court judge in the Fourth Circuit issued a memorandum opinion in United States v. Bailey, which analyzed all aspects of Rule 106 jurisprudence throughout the country and offered suggestions for how the rule should be applied in the Fourth Circuit. ${ }^{198}$ The Court explicitly noted the confusion within the circuit and stated that "until this split in authority has been resolved, a court may allow inadmissible evidence

${ }^{193} I d$. at 1163 .

19484 F.3d 692, 696 (4th Cir. 1996); see also United States v. Lentz, 524 F.3d 501, 526 (4th Cir. 2008) ("Rule 106 does not ... render admissible the evidence which is otherwise inadmissible under the hearsay rules.") (quoting Wilkerson); United States v. Hassan, 742 F.3d 104, 134 (4th Cir. 2014) (Not only does the Rule of Completeness not allow otherwise inadmissible evidence, it does not "require the admission of self-serving, exculpatory statements made by a party which are being sought for admission by that same party.") (internal quotation marks and citation omitted).

195264 F.3d 391, 414 (4th Cir. 2001) (overruled on other grounds by United States v. Chamberlain, 868 F.3d 290 (4th Cir. 2017)).

${ }^{196} I d$.

${ }^{197}$ Id.

198322 F. Supp. 3d 661 (D. Md. 2017) (memorandum opinion). 
under the completeness doctrine[.]"199

\section{(b) The Innovative Approach of the Seventh Circuit}

Early on, the Seventh Circuit introduced a novel method for dealing with Rule of Completeness questions. In United States v. LeFevour, the Court held that "[i]f otherwise inadmissible evidence is necessary to correct a misleading impression, then either it is admissible for this limited purpose by force of Rule 106, or, if it is inadmissible ... the misleading evidence must be excluded too." 200 Thus, if the opposing party cannot complete the misleading statement, the proposing party cannot offer it in the first place. This interpretation attempts to reach a middle ground between the competing views adopted in the other circuits. ${ }^{201}$

LeFevour reasoned that the only legitimate purpose for admitting otherwise inadmissible material is "pulling the sting from evidence" that an opposing party seeks to use against the other. ${ }^{202}$ This objective is achieved either by excluding the entire statement or admitting the truncated portion only to correct a misleading impression. ${ }^{203}$ Following this path allows misleading evidence to be neutralized without permitting Rule 106 to "override every privilege and other exclusionary rule of evidence in the legal armamentarium."204

Although several other courts, including those in the Seventh Circuit, ${ }^{205}$ have cited LeFevour as precedent for allowing the use of otherwise inadmissible evidence under Rule 106,

${ }^{199} \mathrm{Id}$. at $675-76$.

200798 F.2d 977, 981 (7th Cir. 1986) (internal citation omitted).

201 See Michael A. Hardin, This Space Intentionally Left Blank: What to do When Hearsay and Rule 106 Completeness Collide, 82 FordHAM L. REV. 1283, 1314-15 (2013).

${ }^{202}$ LeFevour, 798 F.2d at 1315.

203 See Hardin, supra note 211.

${ }^{204}$ LeFevour, 798 F.2d at 1315.

${ }^{205}$ See United States v. Reese, 666 F.3d 1007, 1019 (7th Cir. 2012) (citing LeFevour as precedent for admitting otherwise inadmissible evidence to correct misleading impressions under Rule 106.) 
none have adopted the suggestion that misleading evidence in its entirety should be excluded. ${ }^{206}$

Thus, LeFevour s remains an interesting anomaly in Rule of Completeness jurisprudence.

(4) Scholarly Work which Argues that Rule 106 Admits the Inadmissible

Many evidence scholars ${ }^{207}$ also unequivocally embrace the position of a broad interpretation of Rule 106. For example, McCormick criticizes a literalist reading of the rule:

It is sometimes stated that the additional material may be introduced only if it is otherwise admissible. However, as a categorical rule, that is unsound. In particular, the statement is sometimes inaccurate as applied to hearsay law. At least when the other passage of the writing or statement is so closely connected to the part the proponent contemplates introducing that it furnishes essential context for that part, the passage becomes admissible on a nonhearsay theory. ${ }^{208}$

Wright \& Graham agree for a number of reasons. ${ }^{209}$ First, nothing in the facial language of Rule 106 "limits the material used for completeness to evidence that satisfies the requirements

206 See Baker, supra note 10, at 301-02 \& n.117.

207 See, e.g., Faust F. Rossi, Evidence: 1999-2000 Survey of New York Law, 51 SYRACUSE L. REV. 489, 498-99 (2001) In discussing the view that Rule 106 only allows admissible evidence for completion, Rossi stated: This approach makes little sense. If the explanation required to prevent distortion must be admissible independent of its corrective function, then the purpose of the rule of completeness is defeated. Either the explanatory statement is non-hearsay because it is being offered for the limited purpose of providing context or avoiding distortion or it should be admitted as a form of rebuttal exception to the rule against hearsay.

See also WRIGHT ET AL., supra note 2, at $§ 5078.1$, nn.42 \& 44-49 for a list of scholarly evidence writers who take the position that Rule 106 permits the use of inadmissible evidence for completion purposes.

${ }^{208}$ See MCCORMICK ET AL., supra note 57, at 395-96.

209 See WRIGHT ET AL., supra note 2, at $\S 5078.1$. 
of the other exclusionary rules." 210 The Advisory Committee's Note is also silent on the issue, but it does point to California's codification of the common law Rule of Completeness as one of the models for Rule $106 .^{211}$

Second, when the Advisory Committee first published the Preliminary Draft of Rule 106, the Justice Department wanted to include the words "which is otherwise admissible" to the clause describing material used for completion purposes. ${ }^{212}$ The Advisory Committee rejected this proposal, as did the Senate Judiciary Committee when the Justice Department appealed to it for inclusion of the words. ${ }^{213}$

Third, even though Rule 106 is ambiguous on the point, Rule 102's requirements of fairness in administration, ascertainment of truth, and justly determined proceedings seem to require the use of inadmissible evidence for completeness in some cases. ${ }^{214}$ As Wright \& Graham stated, "No one has ever explained how these standards would be met by a construction that would allow a party to present evidence out of context so as to mislead the jury, then assert an exclusionary rule to keep the other side from exposing his deception."215

Finally, Rule 102 also encourages the "growth and development of the law of evidence." ${ }^{216}$ To achieve this, it is necessary "to look at the prior law in federal courts to discover the background against which Rule 106 was drafted."217 This exercise leads back to the federal common law Rule of Completeness, which allowed the use of inadmissible evidence to complete truncated statements. ${ }^{218}$

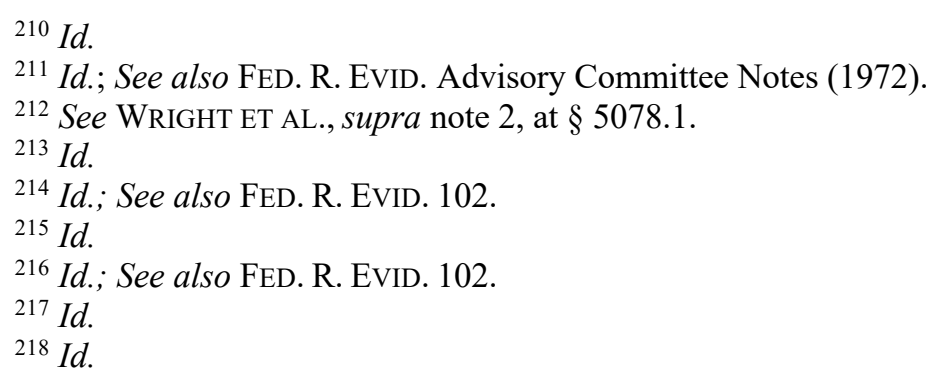




\section{A CASE Study In Confusion: How Utah Courts Have StRugGled with Rule 106 AND THE DOCTRINE OF COMPLETENESS}

The questions of whether Rule 106 applies to oral statements and makes otherwise inadmissible evidence admissible under the purposes of completion have stymied many a court across the nation. Utah provides an excellent case study of courts that have struggled with these issues.

\section{A. STATE V. JONES}

In February of 2004, a young woman was found on the floor of her car stabbed to death. ${ }^{219}$ After testing DNA evidence found at the crime scene, police located Michael Jones and interviewed him in April of 2004. ${ }^{220}$ Jones told officers that he helped the victim purchase crack cocaine on the night of her murder but that afterward he had returned to the homeless shelter where he had been staying and didn't know anything about the killing. ${ }^{221}$ The case went cold for two years. ${ }^{22}$ After more extensive DNA testing definitively matched Jones's DNA to DNA found at the crime scene, Jones was interviewed again in May of 2006, 223 arrested, and charged with the murder. ${ }^{224}$

At trial, Detective Knighton testified as a witness for the state. ${ }^{225}$ He described Jones's

\footnotetext{
${ }^{219}$ State v. Jones, 345 P.3d 1195, 1200-01 (Utah 2015).

${ }^{220} \mathrm{Id}$.

${ }^{221} I d$.

${ }^{222}$ Id. at $1201-02$.

${ }^{223} \mathrm{Id}$. at 1202.

${ }^{224} \mathrm{Id}$.

${ }^{225}$ Id. at 1209.
} 
2004 interview and then testified extensively about his 2006 interview. ${ }^{226}$ The 2006 interview, which had also been videotaped, was much longer, and the police asked more detailed questions. ${ }^{227}$ While Detective Knighton testified, copies of the interview transcripts were with him on the stand, but they were not entered into evidence. ${ }^{228}$ At one point during his testimony the detective even read directly from the transcript. ${ }^{229}$ When the State's direct examination of Detective Knighton was finished, defense counsel attempted to introduce the video tape of Jones's entire 2006 interview with police. ${ }^{230}$ The State objected, and the district court ruled that the video tape was inadmissible hearsay under Rule $801 .{ }^{231}$ Jones was later found guilty of the murder. ${ }^{232}$ Jones appealed and alleged as part of his appeal that the trial court erred by not admitting the videotape of the full interview. ${ }^{233}$

The Utah Supreme Court began its analysis by explaining the Utah version of Rule 106. ${ }^{234}$ The rule "codifies in part the common law 'rule of completeness,' which permits introduction of an otherwise inadmissible statement if the opposing party introduces a portion of the statement." ${ }^{235}$ It thus serves two purposes: (1) it serves a protective function, designed to prevent a "misleading impression created by taking matters out of context"; and (2) "it establishes a 'fairness' standard that requires "admission of those things that are relevant and necessary to qualify, explain, or place into context the portion already introduced."236

The Court then went on to address the two threshold issues raised by Jones's argument.

${ }^{226} \mathrm{Id}$.
${ }^{227} \mathrm{Id}$.
${ }^{228} \mathrm{Id}$.
${ }^{229} \mathrm{Id}$.
${ }^{230} \mathrm{Id}$.
${ }^{231} \mathrm{Id}$.
${ }^{232} \mathrm{Id}$. at 1202.
${ }^{233} \mathrm{Id}$. at 1209.
${ }^{234} \mathrm{Id}$. at 1210.
${ }^{235} \mathrm{Id}$.
${ }^{236} \mathrm{Id}$. (footnotes omitted).


First, Mr. Jones argued, and the State conceded, "that rule 106 applies to transcribed oral statements that are used extensively at trial but are not actually introduced into evidence"; and second, "the State argue[d] that Mr. Jones's statements in the second interview constitute[d] inadmissible hearsay and that rule 106 cannot overcome rule 802's prohibition against hearsay." ${ }^{237}$ Although noting that the Court had never directly addressed or decided these two issues, ${ }^{238}$ the Court determined that it was unnecessary to resolve either of them because the case failed on the merits. ${ }^{239}$

The Court explained that "[i]t is the duty of the trial court to determine which portions of the writing or recording ought in fairness be considered at the same time. This means that a court need only introduce those portions that, in its discretion, are necessary to qualify, explain, or place into context the portion already introduced." ${ }^{240}$ The Court then reviewed the trial record and determined that Detective Knighton's testimony had sufficiently contextualized and accurately related the statements and substance of the second police interview. ${ }^{241}$ Therefore, there had been no distorted or misleading statements that could only be corrected by introducing the entire video recording of the interview. The trial court had not abused its discretion, and Rule 106 was never triggered in the first place. ${ }^{242}$

This analysis is consistent with Wigmore's treatment of the subject of oral utterances. ${ }^{243}$ Wigmore explained that the "general rule, universally accepted, is ... that the substance or effect of the actual words spoken will suffice, the witness stating this substance as best he can from the impression left upon his memory. He may give his 'understanding' or 'impression' as to the net

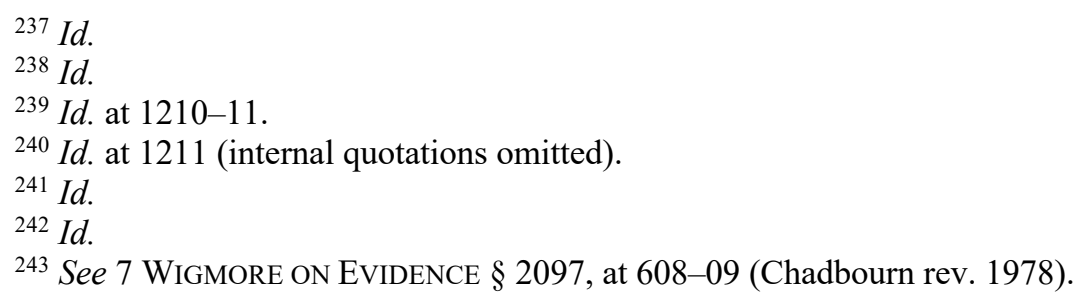


meaning of the words heard."244 The rule applies to admissions, conversations, and even confessions. ${ }^{245}$ Wigmore's rule is based on a premise that memory of an oral statement can only last so long. People are often unable to retain precise words and only remember the general substance of what was said. However, Wigmore wrote his treatise before the days of video recorded and digitally transcribed confessions. Now, courts and juries can hear precisely what was said because it has been preserved as it was originally spoken. Not only is this preferable for defendants who may be worried about the manipulation of their confessions, but it is also easier for trial judges to perform a Rule 106 fairness analysis and determine if the truncated statement has been used in a manipulative and misleading way.

By allowing Detective Knighton to testify in Jones about the oral confession without requiring that the transcript or the video be admitted, the Court may have inadvertently encouraged future abuse of the adversary system, giving law enforcement agents an incentive to avoid admitting the transcript and testifying only to a defendant's inculpatory statements, knowing that the exculpatory portions can be hidden under the guise of a later hearsay objection. Although Detective Knighton provided an accurate summary of the police interview in this case, there is the potential for abuse in the future.

\section{B. STATE V. SANCHEZ ${ }^{246}$}

As described in the Introduction, Sanchez involved another horrific death of a young woman, this time at the hands of her boyfriend. ${ }^{247}$ James Sanchez viciously tortured his girlfriend

\footnotetext{
${ }^{244} I d$. at 609.

${ }^{245} I d$.

${ }^{246}$ For an in-depth treatment of the facts of this case, see discussion infra Section I.

247 State v. Sanchez, 422 P.3d 866 (Utah 2018).
} 
to death over the course of seven hours. ${ }^{248}$ Sanchez told detectives in a recorded and transcribed interview that he had committed the murder, but only because he was under extreme emotional distress at the time. ${ }^{249}$ His girlfriend allegedly told him that she was having an affair with his brother and refused to end the relationship. ${ }^{250}$ At trial, the State introduced the inculpatory statements made by Sanchez during the interview through the testimony of a detective, but the Court excluded Sanchez's statements about the alleged affair on the grounds that they were selfserving hearsay. ${ }^{251}$ The jury convicted Sanchez of first-degree murder. ${ }^{252}$ Sanchez appealed, claiming that if his statements had been admitted, they "would have supported his claim for a reduced charge based on special mitigation for extreme emotional distress." 253

The Utah Court of Appeals engaged in a detailed Rule 106 analysis ${ }^{254}$ and determined that Sanchez's statement had been improperly excluded under the rule's fairness standard. ${ }^{255}$ The Court was particularly worried that, because Sanchez did not testify at trial, there was no evidence of Sanchez's explanation of the murder. ${ }^{256}$ The appellate court disagreed with the trial court's hearsay analysis, explaining that "[t]here is no legal principle which excludes statements or conduct of a party solely on the ground they are self-serving. If otherwise admissible, a party has as much right to his own evidence as to the evidence of any other witness." ${ }^{257}$ In fact, Sanchez's statement was necessary to “qualify, explain, or place in context the portion of his

${ }^{248} I d$. at 868.

${ }^{249} I d$.

${ }^{250} \mathrm{Id}$.

${ }^{251} \mathrm{Id}$.

${ }^{252} \mathrm{Id}$. at 869 .

${ }^{253} \mathrm{Id}$. at $868-69$.

${ }^{254}$ State v. Sanchez, 380 P.3d 375, 380-385 (Utah App. 2016) vacated by State v. Sanchez, 422 P.3d 866, 870 (Utah 2018).

${ }^{255} \mathrm{Id}$.

${ }^{256}$ Id. at 381. See also State v. Leleae, 993 P.2d 232, 242-43 (Utah App. 1999) (There the Court found that the fairness standard did not require admission of a self-serving statement but only because the "defendant had an adequate opportunity during cross-examination to put the selected portions of his statement in context, and other testimony supported his version of the events.").

${ }^{257}$ Id. (quoting State v. Johnson, 671 P.2d 215, 216 (Utah 1983) (per curiam opinion). 
confession introduced by the detective's testimony." 258

The Appeals Court also pointed to Rule 807 of the Utah Rules of Evidence, also known as the residual exception, which provides that "a hearsay statement is not excluded by the rule against hearsay even if the statement is not specifically covered by a hearsay exception" so long as "admitting it will best serve the purposes of these rules and the interests of justice." ${ }^{259}$ Rule 106 can thus operate to create a residual hearsay exception under the bounds of Rule 807 because "it is difficult to see how a statement that in fairness ought to be considered would not serve the interests of justice." 260 In sum, the Court concluded "that rule 106 allows the admission of otherwise inadmissible hearsay if under the fairness standard the evidence should be considered." ${ }^{261}$ However, although the Court concluded that the statement should have been admitted, the Court found that it was a harmless error because there was no reasonable probability the jury, having heard the statement, would have decided the case differently. ${ }^{262}$

The decision was appealed and heard by the Utah Supreme Court. ${ }^{263}$ The court began with a necessary threshold question: "Does the evidence to be admitted qualify as a writing or recorded statement under rule $106 ?{ }^{264}$ Somewhat surprisingly, neither party briefed this question, and the Court felt that it could not properly answer it either. ${ }^{265}$ The problem, the Court explained, was neither party introduced the actual transcript of the detective's interview with

${ }^{258} \mathrm{Id}$. (citation and internal quotation marks omitted).

${ }^{259}$ UTAH R. EvID. 807 \& 807(a). (The Advisory Committee Notes state that this rule is the federal rule, verbatim. Meaning, this same reasoning that completeness evidence is a residual exception to the hearsay rules could also be applied at the federal level.).

${ }^{260}$ See Sanchez, 380 P.3d 375, at 384.

${ }^{261} \mathrm{Id}$. at 382 .

${ }^{262} \mathrm{Id}$. at 388 .

${ }^{263}$ State v. Sanchez, 422 P.3d 866, 870 (Utah 2018) ("The court of appeals held that the trial court should have admitted the evidence under rule 106, but that the error was harmless. Mr. Sanchez appealed the harmless error determination. The state cross-appealed the rule 106 decision.") (internal citation omitted).

${ }^{264} I d$. at 872.

${ }^{265} I d$. 
Sanchez into evidence at trial, which would have undoubtedly made it a recorded statement subject to Rule $106 .{ }^{266}$ While the detective was on the stand, he testified extensively about his conversation with Sanchez and used the transcript on multiple occasions to refresh his memory under Rule $612,{ }^{267}$ but the transcript was never admitted. ${ }^{268}$ Further, it was unclear from the record whether the prosecution or the detective ever directly quoted from the transcript during the detective's testimony. ${ }^{269}$ As a result, the Court was unable to determine how extensively the transcript had been used. ${ }^{270}$ The Court pointed out it had "previously left open the question of whether 'rule 106 applies to transcribed oral statements that are used extensively at trial but are not actually introduced into evidence' ... and it certainly left open the question ... if transcribed oral statements are not used extensively at trial." ${ }^{271}$

Because the extent of the transcript's use at trial was a mystery, and the threshold applicability of Rule 106 remained in serious doubt, the Court declared that it "need not reach the issues of whether rule 106 would apply to the prosecution's use of the transcript or require the admission of statements that would otherwise be inadmissible hearsay." ${ }^{\text {272 }}$ The Court acknowledged the importance of the admissibility question of Rule 106 evidence but found it unnecessary to decide the issue because any potential error in the case was harmless. ${ }^{273}$ Thus, the Utah Supreme Court vacated the portion of the Court of Appeals decision that concerned Rule 106. ${ }^{274}$ And with that, Utah's stance on the Rule of Completeness remained an open question. This constrained interpretation of Rule 106 may have unintended consequences. It

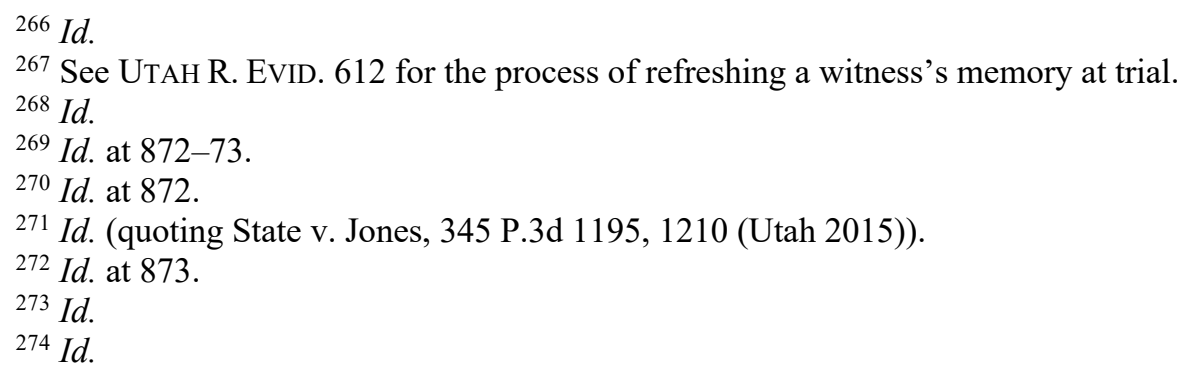


encourages prosecutors to abuse the adversary system by not admitting transcripts of police interviews into evidence. Law enforcement officials may take the stand, testify about all the inculpatory statements they remember the defendant making, and remain safe in the knowledge that the exculpatory statements are hidden away in an unreachable transcript. ${ }^{275}$ The Utah Supreme Court in Sanchez noted that, because the detective used the transcript to refresh his memory on the stand, Sanchez was provided with specific options under Rule 612(b) that he could have employed including the ability "to introduce in evidence any portion [of the writing] that relates to the witness's testimony. ${ }^{276}$ While this may have been true in Sanchez, this suggestion has only taught prosecutors in future cases to ensure their witness's memory need not be refreshed before taking the stand.

Because both Jones and Sanchez involved grisly murders, unsympathetic defendants, and procedural complications, neither was the ideal vehicle for a full analysis of Rule 106. However, the problems typified by these two cases are likely to be replicated in later cases, not just in Utah but nationwide. Thus, the Federal Advisory Committee on the Rules of Evidence is the most appropriate and expeditious venue for a revision of the Rule.

\section{RECOMMENDATIONS FOR AMENDING RULE 106}

In its current embodiment, Federal Rule of Evidence 106 only applies to a "writing or recorded statement." 277 This language should be changed to include oral statements as well.

\footnotetext{
${ }^{275}$ A defendant may not rely upon their own use of the transcript to trigger admissibility under Rule 106. UTAH R. EVID. 106 only allows "an adverse party [to] require the introduction" of a writing or recorded statement when "a party introduces all or part of a writing or recorded statement." (emphasis added).

276 See Utah R. Evid 612(a) \& 612(b) (“"W]hen a witness uses a writing to refresh memory ... [a]n adverse party is entitled to have the writing produced at the hearing, to inspect it, to cross-examine the witness about it, and to introduce in evidence any portion that relates to the witness's testimony.

${ }^{277}$ UTAH R. EVID. 106.
} 
While courts are right to be wary of the problems caused by oral evidence, ${ }^{278}$ the Advisory Committee could mitigate these issues with a careful explanation of how the process concerning oral statements would work. ${ }^{279}$ When oral evidence is offered for completeness, it should face greater scrutiny than written or recorded statements. Trial courts would retain broad discretion to consider factors such as trustworthiness and reliability; keeping in mind, however, that while "some oral statements are disputed and difficult to prove, others are not."280

For example, recorded confessions given to law enforcement officers, summarized confessions transcribed in officers' notes, or oral statements that were witnessed by multiple people would all qualify as oral statements with a high indicia of reliability. Thus, a trial court could admit the evidence for the purpose of completion. While the desire to avoid "he said, she said" disputes is a legitimate concern for trial courts, those concerns do not justify creating a blanket prohibition against oral statements. ${ }^{281}$ Such a comprehensive ban is unwarranted, and it invites abuse. $^{282}$

Further, Rule 106 should be extended to allow otherwise inadmissible evidence to be admitted solely on the grounds of completing a misleading statement or placing it within its necessary context. To prevent any abuse that might occur under this expanded application, the Advisory Committee should set parameters, carefully circumscribing this right and ensuring proper application of the "fairness" requirement embodied in the rule language.

First, the doctrine of completeness embodied in Rule 106 should not be triggered unless a truncated statement has been introduced that creates a misleading impression. The otherwise

278 See discussion, supra Section III.A.2.

279 The Utah Supreme Court already provided an excellent example of this process in its opinion in State $v$. Cruz-Meza, 76 P.3d 1165 (Utah 2003). See discussion of the case, supra Section III.A.2.

${ }^{280}$ United States v. Bailey, 322 F. Supp. 3d 661, 670 (D. Md. 2017) (memorandum opinion).

${ }^{281} \mathrm{Id}$.

${ }^{282} I d$. 
inadmissible evidence used for completion must be not only relevant but essential to clarifying or explaining the previously admitted statement.

Second, parties must be prepared to show with some precision how the incomplete evidence has been taken out of context and in what way it is misleading. Judges would not have to take a party's assertions at face value. ${ }^{283}$ In fact, under Rule 104(c), the court could conduct a preliminary hearing to consider the evidence and determine its admissibility for completion purposes. ${ }^{284}$ For example, in United States v. Soures, the Third Circuit created a four-part test to determine when remainder evidence "ought in fairness be considered contemporaneously" with its truncated portion. ${ }^{285}$ Under that test, once it has been established that only a part of a statement has been introduced, the trial court must then consider whether the remainder evidence "is necessary to (1) explain the admitted portion, (2) place the admitted portion in context, (3) avoid misleading the trier of fact, or (4) insure a fair and impartial understanding." ${ }^{286}$ If the Advisory Committee embraced this test, it would assist trial court judges in making determinations on Rule 106 evidence and would create precedents that were clear and consistent.

Third, a trial court should be especially receptive to Rule 106 completion evidence when it implicates a party's constitutional rights. ${ }^{287}$ This happens most often in criminal cases where

${ }^{283} I d$. at 668 .

${ }^{284}$ See UTAH R. EvID. 102 ("The court must conduct any hearing on a preliminary question so that the jury cannot hear it if: ... the hearing involves the admissibility of a confession; ... or justice so requires.").

285736 F.2d 87, 91 (3d Cir. 1984). Many other courts have adopted the four-part test as well. See, e.g., United States v. Velasco, 953 F.2d 1467, 1474-75 (7th Cir. 1992); United States v. Lopez-Medina, 596 F.3d 716, 735 (10th Cir. 2010).

${ }^{286}$ Soures, 736 F.2d at 91 . Beyond this initial test, Wright \& Graham have identified additional factors that can also help courts identify when completion evidence should be permitted under the fairness doctrine of Rule 106:

(1) Can the misleading impression be dispelled by other means?; (2) How much evidence is needed to dispel the misleading effect?; (3) How strong is the evidence admitted and omitted?; (4) How long will repair be delayed if not accelerated?; (5) What is the consequential fact to be proved?; (6) How much will completion disrupt or prejudice proponent?; and (7) What part did counsel play in truncating the evidence?

See Wright ET AL., supra note 2, at § 5077.2.

${ }^{287}$ See WRIGHT ET AL., supra note 2, at $\S 5077.2$. 
the prosecution introduces evidence, usually the defendant's own confession, that can only be effectively rebutted by the defendant taking the stand and waiving his or her constitutional right not to testify. ${ }^{288}$ "A criminal defendant should not be forced to choose between leaving the government's distorted presentation unanswered and surrendering" his or her Fifth Amendment right. ${ }^{289}$ This situation clearly frustrates the principle of fairness explicitly stated in the language of Rule 106. Several courts have adopted this rationale as part of the fairness inquiry when deciding whether to allow otherwise inadmissible evidence, ${ }^{290}$ and the Federal Rules should do the same.

Fourth, material admitted for completeness under Rule 106 should not be used as substantive evidence. To ensure this directive is followed, courts must issue a limiting instruction and direct the jury that the completion evidence may only be used to give meaning to the truncated statement and not for the truth of the matter asserted. ${ }^{291}$ Many evidence scholars and courts also embrace this position. ${ }^{292}$ It addresses the fear that parties will take advantage of Rule 106 to make an end-run around other exclusionary rules and admit testimony evidence in the name of completion.

These recommendations, if adopted, will help guide and unify federal courts'

${ }^{288}$ See U.S. CONST. amend. V. ("No person ... shall be compelled in any criminal case to be a witness against himself ...").

${ }^{289}$ See Baker, supra note 10, at 305 (internal quotation marks and citation omitted).

${ }^{290}$ See WRIGHT ET AL., supra note 2, at § 5077.2; see also United States v. Marin, 669 F.2d 73, 85 n. 6 (2d Cir. 1982) (quoting United States v. Walker, 652 F.2d 708, 713 (7th Cir. 1981)):

[W] hen the government offers in evidence a defendant's confession and in confessing the defendant has also made exculpatory statements that the government seeks to omit, the defendant's Fifth Amendment rights may be implicated. In such circumstances ... the Fifth Amendment right to remain silent is violated when the omission "paint(s) a distorted picture ... which (the defendant is) powerless to remedy without taking the stand.

${ }^{291}$ See UTAH R. EVID. 105 ("If the court admits evidence that is admissible against a party or for a purpose - but not against another party or for another purpose - the court, on timely request, must restrict the evidence to its proper scope and instruct the jury accordingly.").

${ }^{292}$ See WrIGHT ET AL., supra note 2, at § 5078; see also Churchfield v. State, 769 A.2d 313, 327 (Md. App. 2001) ("remainder is received as an aid in construction of the utterance as a whole and is not in itself testimony"). 
completeness jurisprudence.

\section{CONCLUSION}

The doctrine of completeness, a centuries-old stalwart of Anglo-American jurisprudence, now partially enshrined in the Federal Rules of Evidence, is one tool designed to ensure that the American judicial system achieves the grand ideals of truth, justice, and fairness. However, this goal cannot be realized if parties to a dispute are allowed to unfairly manipulate the adversarial process. Taking an opponent's statements and mining them for only a few choice words and phrases, while attempting to exclude the rest, is an underhanded scheme that does not serve the interests of justice.

The common law Rule of Completeness guarded against such abuses with a broad policy of admitting evidence that was necessary to correct a misleading impression. Federal Rule of Evidence 106 followed in the common law's footsteps. However, in its zeal to correct the common law's shortcoming by adding an acceleration clause, the assurance of protection against truncated statements was somehow lost in translation. It is time for the Federal Rules of Evidence to reclaim two important pieces of the completeness puzzle: (1) oral statements and (2) otherwise inadmissible evidence used for the purpose of completion. If fairness is the goal of Rule 106, it cannot be fully achieved until the modern completeness doctrine more closely resembles its common law predecessor. 